Kıymaz, M. S. ve Doyumğaç, ì. (2020). Türkçe öğretmeni adaylarının dinlediklerinden hareketle hazırlıksız konuşma başarıları: Karma yöntem araştırması. Ana Dili Eğitimi Dergisi, 8(4), 1049-1070.

Ana Dili Eğitimi Dergisi
Journal of Mother Tongue Education
www.anadiliegitimi.com
Geliş/Received: 12.04 .2020 Kabul/Accepted:30.06.2020
Araştırma Makalesi / Research Paper

\title{
Türkçe Öğretmeni Adaylarının Dinlediklerinden Hareketle Hazırlıksız Konuşma Başarıları: Karma Yöntem Araştırması ${ }^{*}$
}

\author{
Mustafa Said KIYMAZ** \\ ibrahim DOYUMĞAÇ
}

\begin{abstract}
Öz
Bu araştırmanın temel amacı, Türkçe öğretmeni adaylarının dinlediklerinden hareketle yaptıkları hazırlıksız konuşma başarılarını belirlemektir. Karma yöntemin kullanıldığı araştırma, açımlayıcı desene dayanmaktadır. Araştırmanın çalışma grubu, Adıyaman Üniversitesinde 2019-2020 eğitimöğretim yılında öğrenim gören Türkçe öğretmeni adaylarıdır. Kolay ulaşılabilir örneklemin kullanıldığı araştırmanın nicel veri toplama aracı, Konuşma Becerisi Derecelendirme Ölçeği ve Konuşma Becerisi Gözlem Formu'dur. Araştırmanın nitel veri toplama aracı ise Türkçe öğretmeni adaylarının dinlediklerinden hareketle yaptıkları hazırlıksız konuşmalarının ses kaydından yazıya aktarılmış metinleridir. Araştırmanın nicel verileri, SPSS 21.0 istatistik paket programıyla hesaplanmıştır. Nitel veriler ise içerik analiziyle incelenmiştir. Nicel verilerin güvenirlik ve geçerliliğ için Konuşma Becerisi Derecelendirme Ölçeği'nin Kendall's Tau Katsayısı hesaplanırken; Konuşma Becerisi Gözlem Formu için uzmanlar arası uyum katsayısı hesaplanmıştır. Araştırmanın sonucunda Türkçe öğretmeni adaylarının dinlediklerinden hareketle yaptıkları hazırlıksız konuşmalarında, bürünsel (prozodik) unsurları doğru kullanamama, cümleler arasında mantıksal ve anlamsal bağlantıları yapamama, deyim ve atasözü kullanmama, bağdaşıklık, tutarlılığı sağlayamama ve söylem oluşturamama gibi açılardan zayıf oldukları anlaşılmıştır. Söz konusu adayların konuşmalarında dilin işlevsel yönünden yararlanmadıkları ve dili yetkin kullanmada başarısız (geliştirebilir düzeyde) oldukları sonucuna ulaşılmıştır.
\end{abstract}

Anahtar Kelimeler: Türkçe öğretmeni adayları, dinleme ve hazırlıksız konuşma, konuşma başarısı.

\section{Listening-Based Impromptu Speech Achievements of Pre-Service Turkish Language Teachers: A Mixed Method Research}

\begin{abstract}
The present study aimed to determine the listening-based impromptu speech achievements of pre-service Turkish language teachers. In the study, a mixed method based on exploratory design was employed. The study group included pre-service Turkish language teachers attending Adıyaman University in Turkey during the 2019-2020 academic year. The convenience sampling method was adopted in the study and quantitative data were collected with Speaking Skills Rating Scale and Speaking Skills Observation Form. The qualitative data were collected with the transcripts of the impromptu speeches by the pre-service Turkish teachers based on the texts they have listened to. Quantitative study data were analyzed with SPSS 21.0 statistics software. Qualitative data were analyzed with content analysis. Kendall's Tau Coefficient was employed to
\end{abstract}

\footnotetext{
* Bu araştırmanın Etik Kurul İzni, 11/06/2020-1 Etik Kurul toplantı tarihi ve karar sayısı ile Adıyaman Üniversitesi Sosyal ve Beşeri Bilimler Etik Kurulu tarafından uygun bulunarak verilmiştir.

** Dr. Öğretim Üyesi, Adıyaman Üniversitesi Eğitim Fakültesi, Türkçe Eğitimi Ana Bilim Dalı, Adıyaman, mustafasaid_65@hotmail.com, ORCID: 0000-0003-3821-5499.

*** Arş. Gör., Adıyaman Üniversitesi Eğitim Fakültesi, Türkçe Eğitimi Ana Bilim Dalı, Adıyaman, idoyumgac@adiyaman.edu.tr, ORCID: 0000-0002-8234-7555.
} 
determine the reliability of the Speaking Skills Rating Scale and interrater agreement coefficient was used for the Speaking Skills Observation Form. The study findings revealed that the pre-service Turkish language teachers were poor in the correct use of prosodic elements, rational and semantic connections between the sentences, utilization of idioms and proverbs, coherence, consistency, and discourse in their impromptu speeches. It was concluded that the pre-service teachers did not utilize the functional aspect of the language in their speeches and they failed in competent use of the language (in a developable level).

Keywords: Pre-service Turkish language teachers, listening and impromptu speech, speaking achievement.

\section{Giriş}

Konuşma/k var olmak, kendini keşfetmek, kendi özünü değerli kılmak ve kendisiyle muhatap olana değer katarak herhangi bir konuda duygu ve düşüncelerini eyleme, söze dönüştürme yetisi/becerisidir. Nasıl ki insanı diğer canlı varlıklardan ayıran eylem konuşmaysa aynı zamanda insanı da insandan ayıran şey, genelde konuşma yetisi; özelde ise söylemdir. Başka bir deyişle insanı insandan farklı kılan, kişinin kendi özünü de ortaya koyan, konuşmayı daha da özelleştiren, anlamlandıran "kendine has konuşma söylemi"dir. Bütün bunların özünü ise dinleme oluşturmaktadır. Konuşma, anlatma söylemini belirlemede; dinleme ise konuşanın/ konuşucunun/ konuşmacının, söylemini anlamada etkilidir.

Dinleme, sözlü anlama; konuşma ise sözlü anlatma olarak değerlendirilmektedir. İlk edinilen beceri olan dinleme, konuşma becerisini büyük ölçüde etkilemektedir. Sürekli aynı müziği dinleyen, aynı filmi izleyen/dinleyen veya sürekli aynı yayın organında haber izleyen/dinleyen bir insanın konuşma söyleminin de dinlediklerinden/izlediklerinden etkilenmesi doğaldır. Bu iki dil becerisi bireylerin sözel anlama becerisini ön plana çıkarmakta ve kavramsal, anlamsal analizi önemli kılmaktadır. Temelinde sözlü anlamanın yer aldığı dinleme ve konuşma eğitiminde amaç, "sözlü anlama becerilerini geliştirmiş, düşünen, anlayan, sorgulayan, sorun çözen ve geleceğine yön veren bireylerin yetiştirilmesi" olmalıdır (Güneş, 2012: 28). Bu yüzden hayatın her anında iyi bir sözlü anlama becerisi edinmek; dinleme ve konuşma eğitiminin, etkinliklerinin birlikte yapılması ile yakından ilgilidir. İnsan günlük hayatın büyük çoğunluğunu konuşarak ve dinleyerek geçirmektedir (Temizyürek, Erdem ve Temizkan, 2014). Dolayısıyla dinleme (anlama) ve konuşma (anlatma) süreci birlikte düşünüldüğünde bu iki becerinin etkileşimi esnasında sözlü anlama etkileşiminin önemli rol oynadığı söylenebilir. Çünkü dinlenilen konu bir ses aracılığıyla sözlü olarak gerçekleşmektedir. Sözlü anlama "bireyin; konuşmacı, sözlü metin ve ortamla etkileşimi sonunda ön bilgileriyle yeni bilgileri bütünleştirdiği, yeniden anlamlandırdığı, etkileşimsel bir süreç" (Güneş, 2012: 16; Güneş, 2014: 84) olarak tanımlanmaktadır. Bireyin, etkin bir dinleyici veya konuşucu/konuşmacı/konuşur olması için yeni bilgilerle eski bilgileri bir araya getirip kendine özgü söylem oluşturması gerekir. Gündüz ve Şimşek (2014)'e göre konuşmalarında, dile ait ögeleri yerli yerinde kullanan, düzgün cümleler kuran, dilin mantığına ve söz dizimine uygun konuşan bireyler iyi birer dinleyicidir. Çünkü "dinleme ile konuşma arasında doğrudan bir ilgi bulunmaktadır" (Özbay, 2014: 61). Başka bir deyişle "konuşma olduğunda dinleme, dinleme olduğunda ise bir konuşma vardır" (Doğan, 2013: 3).

Sözlü anlatım becerisi duyduğunu anlama becerisinden sonra gelmektedir. Metnin düzenlenişinde bağlantı ögelerinin uygun şekilde kullanılması, konu ilerleme kurallarına ve çeşitliliğine uyulması, uzun süre aynı konunun yinelenmemesi, çok sık konu değiştirerek anlam bütünlüğünün bozulmaması, yeni bilgi vurgulanmasına dikkat çekilmesi, artgönderim, öngönderim ögelerine uyulması, üzerinde durulan konunun aniden değiştirilmemesi sözlü anlatımda olması beklenen ölçütlerdir (Korkut, 2016). Söz konusu bu unsurlar, sözlü anlama ve anlatmada konunun anlaşılmasında etkilidir.

Türkçe öğretmeni adaylarının yakın gelecekte Türkçe öğretmeni sıfatı ile görev alacağı göz önüne alındığında, bu adayların, dinlediklerinden hareketle hazırlıksız konuşma başarılarının zayıf ve güçlü yönlerinin belirlenmesinin önemli olduğu düşünülmektedir. Bu konuşmaların başarı açısından niteliği ve varsa sorunlarının neler olduğunun ortaya konulması, sözlü anlama ve sözlü anlatma becerisi açısından mühimdir. 
Türkçe öğretiminin sorunlarıyla ilgili yapılan araştırmalarda bu sorunların çeşitlilik gösterdiği (Alyılmaz, 2010; Arslan, 2017; Koç ve Kıymaz, 2019) ve hâlâ devam ettiği anlaşıımaktadır. Bu sorunlardan bazıları dinleme, konuşma, okuma ve yazma eğitimi ve becerisi ile ilgilidir. Bu dört temel becerinin sorunları üzerine yapılan birçok araştırma bulunmaktadır. Örneğin, Akkaya, (2012) Türkçe öğretmeni adaylarının "konuşma"; Emiroğlu (2013) ise "dinleme" sorunlarını belirlemiştir. Bunun yanı sıra dışsal bir değişkenin konuşma becerisi üzerindeki etkisini ölçme ya da konuşma becerisine ilişkin durum belirleme araştırmaları da mevcuttur (Bayburtlu, 2019; Bulut, 2015; Bulut, Açık ve Çiftçi, 2016; Bozkurt, 2017; Bozkurt ve Arıca-Akkök, 2019; Çintaş-Yıldız ve Yavuz, 2012; Doğan, 2009; Gürhan, 2013; Kartallığlu, 2018; Kurudayıoğlu, 2003; Maden, 2011; Orhan, Kırbaş ve Topal, 2012; Sallabaş, 2011; Sargın 2006; Sevim, 2012; Temizkan, 2009; Temizkan ve Atasoy, 2016; Yüceer, 2014).

Konuşma eğitiminde olduğu gibi dinleme eğitiminin sadece bir yönünün ele alındığı birçok araştırma bulunmaktadır (Aşıı̆ı̆lu 2009; Aytan, 2011; Ceran 2015; Ceyran, 2016; Çifçi 2001; Doğan 2007; Doğan, 2008; Durukan ve Maden 2010; Epçaçan, 2013; Karadüz, 2010; Karatay, Dolunay ve Savaş, 2014; Karagündüz, 2010; Kemiksiz, 2015; Kurudayıoğlu ve Savaş, 2020; Kurudayıoğlu ve Kiraz, 2020; Maden ve Durukan, 2011; Melanlığlu, 2012a; Melanlıŏlu, 2012b; Özbay ve Çetin 2011; Sevim ve Kaya, 2016; Şahin, 2011; Şahin ve Aydın, 2009; Temur, 2010; Tüzel 2013; Tüzel ve Keleş, 2013; Yazıcı ve Kurudayıoğlu, 2017). Bunun yanı sıra bazı araştırmalar dinleme-okuma ve dinleme-konuşma ilişkisi bağlamında ele alınmıştır. Örneğin dinleme-okuma ilişkisinin bir yönüne Bulut ve Karasakaloğlu (2018); dinleme-konuşma ilişkisine ise Erdem ve Erdem (2015) değinmişlerdir. Erdem ve Erdem (2014) başka bir çalışmalarında da dinleme-konuşma ilişkisine yönelik ölçek geliştirmeyi çalışmışlardır.

Maxvell ve Dornan, (2001: 106) ve Buzan (2001: 97)'a göre sürekli iletişim hâlinde olan bir insan, günün \%30'unu konuşarak \%45'ini ise dinleyerek geçirmektedir (Akt.: Özbay, 2014). Bu oranlar bağlamında düşünüldügünde bir insan günün \%75'ini dinleme-konuşma süreciyle geçirmektedir. Genellikle günlük hayatta, iletişim süreci hazırlıksız konuşma şeklinde gerçekleşmektedir. Bu durum, herhangi bir konuyla ilgili sözlü veya yazılı bir metni dinleme ve bundan hareketle hazırlıksız konuşmanın yapılmasını önemli kılmaktadır. İnsanın günlük hayatın her anında sözlü veya yazılı bir metni dinleme durumunda olduğu düşünülerek Türkçe öğretmeni adaylarııın dinlediklerinden hareketle hazırlıksız konuşmalarının başarı düzeylerinin belirlenmesinin önemli olduğu düşünülmüştür. Bu düşünceden hareketle söz konusu bu araştırma gerçekleştirilmiştir.

$\mathrm{Bu}$ araştırmanın temel amacı Türkçe öğretmeni adaylarının dinlediklerinden hareketle yaptıkları hazırlıksız konuşma başarılarını çeşitli açılardan açıklamaktır. Bu temel amaca bağlı olarak aşağıdaki sorulara cevap aranmıştır:

1.Türkçe öğretmeni adaylarının dinledikleri metinlerden hareketle yaptıkları hazırlıksız konuşmalarındaki söyleyiş, akıcılık, dil yetkinliği ve etkileşim-sunum puanları arasında nasıl bir ilişki vardır?

2.Türkçe öğretmeni adaylarının dinledikleri metinlerden hareketle yaptıkları hazırlıksız konuşmalarının eğilimi (zayıf-güçlü yönü) nasıldır?

3.Türkçe öğretmeni adaylarının dinlediklerinden hareketle yaptıkları hazırlıksız konuşmalarında karşılaşılan sorunlar nelerdir?

\section{Araştırmanın Deseni}

\section{Yöntem}

Karma yönteme dayanan bu araştırma, açımlayıcı desenle gerçekleştirilmiştir. Açımlayııı karma desenin ilk aşamasında toplanan nicel veriler, ikinci aşamada nitel verilerle desteklenmektir. Bu desende nicel veriler, nitel verilerle açıklanmaktadır. Açımlayıcı desene dayanan araştırmalarda ilk aşamada nicel veriler toplanmakta ve daha sonra nicel verileri detaylandırmak için nitel veriler verilmektedir (Delice, 2015; Hacıömeroğlu, 2017). Bu araştırmanın ilk aşamasında "Konuşma Becerisi Derecelendirme Ölçeği" ve "Konuşma Becerisi Gözlem Formu" aracılığıyla nicel verilerin toplanması ve bunların analizi yer almaktadır. Daha sonra ise nicel verileri açıklamak için Türkçe öğretmeni adaylarıın dinlediklerinden hareketle yaptıkları hazırlıksız konuşmaların değerlendirmesi yapılmıştır. Bu nicel ve nitel veriler bağlamında Türkçe öğretmeni adaylarının dinlediklerinden hareketle hazırlıksız konuşma başarı eğilimlerinin zayıf ve güçlü yönleri belirlenmeye çalışılmıştır. 


\section{Örneklem/Çalışma Grubu}

Illetişimin her anında ön plana çıkan iki beceri dinleme ve konuşmadır. İletişimde bu iki becerinin önemli olduğu düşünülerek araştırmanın problem sorusunun temelini teşkil eden bu durum da dikkate alınarak araştırmada kolay ulaşılabilir örneklem türü kullanılmıştır. Kolay ulaşılabilir örneklem türünde araştırmacı, yakın olan ve erişilmesi kolay olan bir durumu seçer. Bu seçim, araştırmaya hız ve pratiklik katar (Yıldırım ve Şimşek, 2013). Adıyaman Üniversitesinde öğrenim gören Türkçe öğretmeni adaylarının örneklemi oluşturduğu araştırma, kırk (40) katılımcıyla gerçekleştirilmiştir. Bu katılımcıların 29'u kadın, $11^{\prime}$ i ise erkektir.

$\mathrm{Bu}$ araştırma, kırk (40) Türkçe öğretmeni adayının hazırlıksız konuşmaları ve araştırmada kullanılan veri araçlarıyla sınırıdır. Ayrıca araştırma 2019-2020 Eğitim-Öğretim Yılı, Türkçe öğretmenliği lisans programının "Anlatma Teknikleri I: Konuşma Eğitimi" dersine ait uygulama bölümünün dört haftasıyla sınırlıdır.

\section{Veri Toplama Araçları}

Bu araştırmanın nicel veri toplama aracı, Bozkurt ve Arıca-Akkök (2019) tarafından geliştirilen "Konuşma Becerisi Derecelendirme Ölçeği" ile "Konuşma Becerisi Gözlem Formu"dur. Bu ölçekler, bizzat araştırmacılardan izin alınarak kullanılmıştır. Bunun yanı sıra araştırma için "Etik Kurul İzni" de alınmıştır. Etik Kurul İzni, 11/06/2020-1 Etik Kurul toplantı tarihi ve karar sayısı ile Adıyaman Üniversitesi Sosyal ve Beşeri Bilimler Etik Kurulu tarafından uygun bulunarak verilmiştir.

Araştırmanın nitel veri toplama aracı ise Türkçe öğretmeni adaylarının dinlediklerinden hareketle yaptıkları hazırlıksız konuşmalarının ses kayıtlarının yazıya aktarııış hâli olan metinlerdir.

\section{Nicel Veri Toplama Araçları}

Konuşma Becerisi Derecelendirme Ölçeği

Konuşma Becerisi Derecelendirme Ölçeği 27 maddeden oluşmaktadır. Bu ölçeğin bazı maddeleri seçimliktir. Ölçek dört alt boyuttan oluşmaktadır. Söyleyiş alt boyutu 6 (1-6. maddeler); akıclık alt boyutu 4 (7-10. maddeler); dil yetkinliği alt boyutu 4 (11-14. maddeler); etkileşim-sunum alt boyutu ise 13 (15-27. maddeler) maddeden oluşmaktadır. Araştırmanın hazırlıksız konuşma üzerine olması nedeniyle araştırmada kullanılan ölçeğin "seçimlik" maddeleri ölçekten çıkarılmamıştır. Ölçekteki derecelendirme; zayıf (1), geliştirilebilir (2), yeterli (3) ve yetkin (4) şeklindedir.

\section{Konuşma Becerisi Gözlem Formu}

Konuşma Becerisi Gözlem Formu, Konuşma Becerisi Derecelendirme Ölçeği gibi zayıf, geliştirilebilir, yeterli ve yetkin olmak üzere dört (4) düzeyin yer aldığı toplam 30 maddeden oluşmaktadır. Gözlem formunun söyleyiş alt boyut maddesi 7 (1-7. maddeler); akıcılık alt boyut maddesi 4 (8-11. maddeler); içerik-dil kullanımı alt boyut maddesi 8 (12-19. maddeler); etkileşimsunum stratejileri alt boyut maddesi ise 11 (20-30. maddeler) tanedir.

\section{Nitel Veri Toplama Aracı}

\section{Hazırlıksız Konuşma Metinleri}

Türkçe öğretmeni adaylarından, dinledikleri farklı metinlerden hareketle hazırlıksız konuşmaları istenmiştir. Dinleme metinleri, 5. sınıf, 6. sınıf, 7. sınıf ve 8. sınıf Türkçe ders kitaplarında yer alan okuma metinlerinin seslendirilmesiyle oluşturulmuştur. Okuma metinlerinin dinleme metinleri şeklinde verilmesinin amacı, söz konusu adayların dinlediklerinden hareketle ne ölçüde konuşabildiklerini tespit etmektir. Hazırlıksız konuşma türü tercih edildiği için metinlerin Türkçe ders kitaplarındaki metinler olmasına dikkat edilmiştir. Öğretmen adaylarının dinledikleri metinden hareketle yaptıkları hazırıksız konuşmalar kayıt altına alınmıştır. Kayda alınan konuşmalar daha sonra yazıya aktarılarak içerik analiziyle çözümlenmiştir. Kırk (40) Türkçe öğretmeni adayının hazırlıksız konuşmaları üç uzman (gözlemci) tarafından incelenerek puanlandırılmıştır.

Hazırlıksız konuşma konusu, Türkçe öğretmeni adaylarına dinletilen farklı türlerdeki metinlerin seslendirilmiş kayıtlarıdır. Türkçe öğretmeni adaylarına farkı türlerdeki metinler dinletilerek onlarla metnin konusu üzerine hazırlıksız konuşmanın yapılmasının amacı ise öğretmen adaylarııın konuyu 
Türkçe Öğretmeni Adaylarının Dinlediklerinden Hareketle Hazırlıksız Konuşma Başarıları: Karma Yöntem Araştırması

anlaşılır bir şekilde ve türe özgü özellikler bağlamında hazırlıksız bir şekilde ne ölçüde konuşabildiklerini belirlemektir. Araştırmada ses kaydının alınma amacı, hazırlıksız konuşmaları çeşitli açılardan izlemek; gözlemin amacı ise araştırma verilerinin tarafsızlığını ortaya koymaktır.

\section{Verilerin Analizi}

Bu araştırmanın veri analizi nicel ve nitel olarak iki aşamada gerçekleştirilmiştir.

\section{Nicel Verilerin Analizi}

Bu araştırmanın nicel verileri Konuşma Becerisi Derecelendirme Ölçeği ile Konuşma Becerisi Gözlem Formu'ndan elde edilen verilerden oluşmaktadır. Araştırmaya katılan kırk (40) Türkçe öğretmeni adayı, dinlediklerinden hareketle hazırlıksız konuşma yaptıkları esnada 3 gözlemci tarafından Konuşma Becerisi Derecelendirme Ölçeği ve Konuşma Becerisi Gözlem Formu’na göre puanlandırılmıştır.

\section{Konuşma Becerisi Derecelendirme Ölçeği}

Konuşma Becerisi Derecelendirme Ölçeği; söyleyiş, akıcılık, dil yetkinliği ve etkileşim-sunum alt boyutu olmak üzere 4 ayrı testten ve 27 maddeden oluşmaktadır. Dört (4) derecelendirme puanından oluşan ölçekte zayıf (1), geliştirilebilir (2), yeterli (3), yetkin (4) puan değerindedir.

Dinletilen farkı metinlerden hareketle Türkçe öğretmeni adayları, uzmanlar/gözlemciler tarafından gözlemlenmiş ve adaylara üç uzman/gözlemci tarafından Konuşma Becerisi Derecelendirme Ölçeği'ne göre zayıf (1), geliştirilebilir (2), yeterli (3), yetkin (4) şeklinde puanlar verilmiştir. Konuşma Becerisi Derecelendirme Ölçeği ile ilgili, katılımcıların maddelerden aldıkları ortalama puanlar ve düzeyleri, tablo 4, 6, 8 ve 10'da ayrıntılı olarak verilmiştir. Örneğin bütün katılımcıların söyleyiş testi birinci maddesinden (1.maddeden) aldığı puanlar birinci uzmana göre 63; ikinci uzmana göre 61; üçüncü uzmana göre 61; bu üç uzmanın toplam puanı 185; bütün katılımcıların birinci maddeden aldığı puanların ortalaması ise 61,66 (geliştirilebilir düzey) olarak ortaya çıkmıştır.

Üç uzmanın/gözlemcinin hangi maddeye kaç puan verdiği ve bu puanların ortalamasının hangi düzeye denk geldiği kırk (40) katılımcının ortalama puanını ortaya koymaktadır. Konuşma Becerisi Derecelendirme Ölçeği'nde çok fazla tekrar eden değerin ve ölçekteki alt boyutlar arasında normal dağılım olup olmadığııı kontrol etmek amacıyla Kendall's Tau Korelasyon Katsayısı hesaplanmıştır.

İlk aşamada ölçeğin, Kolmogorov-Smirnov testine ait anlamlılık değerinin dil söyleyiş alt boyutundan alınan puanlar için 0.000; akıcılık alt boyutundan alınan puanlar için 0,001; dil yetkinliği alt boyutundan alınan puanlar için 0,000; etkileşim-sunum alt boyutundan alınan puanlar için 0,200 olduğu görülmektedir. Bu veriler incelendiğinde ölçekteki alt kategorilerden söyleyiş, akıcılık ve dil yetkinliğinin kendi aralarında normal dağılım gösterdiği; ancak söyleyiş, akıcılık, dil yetkinliği ve etkileşim-sunum alt boyutundaki testlerin normal dağılım göstermediği anlaşılmaktadır. ikinci aşamada Bozkurt ve Arıca-Akkök (2019) tarafından geliştirilen “Konuşma Becerisi Derecelendirme Ölçeği” nin bir bütün olarak normal dağılım göstermediği dikkate alınarak söz konusu ölçeğin Kendall’s Tau Korelasyon Katsayısı hesaplanmıştır. Ölçeğin verileri için korelasyon katsayısının (r) 0,277 olduğu anlaşıımıştır. Anlamlılık değerinin (Sig.) 0,05'ten küçük olması değişkenler arasındaki ilişkinin anlamlılığını göstermektedir. Bu veriler için anlamlılık değeri 0,019'dur.

Dört (4) düzeyden oluşan Konuşma Becerisi Derecelendirme Ölçeği'nde, 1-40 arası puan zayıf (1); 40-80 arası puan geliştirilebilir (2); 80-120 arası puan yeterli düzey (3); 120-160 arası puan ise yetkin (4) düzeydir. Bu derecelendirme ölçeğinden bütün katılımcıların bir maddeden alabileceği en düşük ortalama puan 40; en yüksek ortalama puan ise 160 'tır. Üç (3) uzmanın/gözlemcinin kırk (40) katılımcıya verdikleri puanlar, maddelere ve ayrı kategorideki testlere göre verilerek daha sonra tablolar hâlinde verilmiştir.

\section{Konuşma Becerisi Gözlem Formu}

Araştırmada kullanılan "Konuşma Becerisi Gözlem Formu" için 3 uzmana ait, gözlem puanları söyleyiş, akıcılık, içerik-dil kullanımı ile etkileşim-sunum stratejileri bakımından ayrı ayrı toplanmış ve hesaplanmıştır. 3 uzmanın/gözlemcinin söyleyiş, akıcılık, içerik-dil kullanımı, etkileşim-sunum 
stratejileri maddelerine ait toplam puanları aşağıda verilmiştir. Katılımcıların "Konuşma Becerisi Gözlem Formu"ndaki maddelerden aldıkları puan ortalamaları, tablo 5, 7, 9 ve 11'de ayrıntılı olarak verilmiştir.

Tablo 1.

Konuşma becerisi gözlemcilerinin/uzmanlarının konuşma becerisiyle ilgili toplam gözlem puanları

\begin{tabular}{lccc}
\hline & 1.Gözlemci & 2.Gözlemci & 3.Gözlemci \\
Söyleyiş & 369 & 387 & 390 \\
Akııılık & 222 & 221 & 214 \\
İçerik-dil kullanımı & 369 & 368 & 376 \\
Etkileşim-sunum stratejileri & 589 & 584 & 597 \\
\hline
\end{tabular}

Tablo 1 incelendiğinde 3 gözlemcinin, ölçek maddelerine verdikleri ortalama puanların birbirine yakın olduğu anlaşılmaktadır. Söyleyiş, akıcılık, içerik-dil kullanımı, etkileşim-sunum stratejileri arasındaki puan farkının sebebi maddelerin sayısının farklı olmasıdır. Dolayısıyla toplam gözlem puanı/puanları gözlemci veya madde sayısına bölündüğünde bu farkın yine değişmediği anlaşılmaktadır.

Konuşma Becerisi Derecelendirme Ölçeği gibi gözlem formu puanlaması da ölçek gibi (1) zayıf (1), geliştirilebilir (2), yeterli (3) ise yetkin (4) olarak hesaplanmıştır. Bütün katılımcıların (40 katııımının) gözlem maddelerinden aldığı ortalama puanlar 1-40 arası zayıf (1); 40-80 arası puan geliştirilebilir (2); 80-120 arası puan yeterli (3); 120-160 arası puan ise yetkin (4) olarak değerlendirilmiştir. Bütün katılımcıların bir maddeden alabileceği en düşük ortalama puan 40; en yüksek ortalama puan ise 160'tır. Araştırmanın nicel veri analizi sürecinde Konuşma Becerisi Derecelendirme Ölçeği ile Konuşma Becerisi Gözlem Formu'ndan elde edilen veriler, alt kategorideki testlerin maddelerinin ortalaması dikkate alınarak karşılaştırmalı olarak verilmiştir.

\section{Nitel Verilerin Analizi}

Bu araştırmanın nitel veri analizi Türkçe öğretmeni adaylarının hazırlıksız konuşma kayıtlarının yazıya aktarılmasıyla yapılmıştır.

\section{Hazırlıksız Konuşma Metinleri}

Bu araştırmada öncelikle Türkçe öğretmeni adaylarına farklı türlerde metinler dinletilip bu metinlerden hareketle onların yaptıkları hazırlıksız konuşmalar ses kaydına alınmıştır. Türkçe öğretmeni adaylarının hazırıksız konuşmaları daha sonra yazıya aktarılarak analiz edilmiştir. Araştırmanın amacı bağlamında Türkçe öğretmeni adaylarının hazırlıksız konuşmaları üç uzman tarafından gözlemlenmiş ve yazıya aktarılan kayıtlar aynı uzmanlar tarafından içerik analizine tabi tutulmuştur. Türkçe öğretmeni adaylarının hazırlıksız konuşmaları ses kaydına alındığı gibi "Konuşma Becerisi Derecelendirme Ölçeği" ve "Konuşma Becerisi Gözlem Formu" ile değerlendirilerek karşılaştırılmıştır.

$\mathrm{Bu}$ araştırmanın verileri, karma araştırmanın özellikleri doğrultusunda değerlendirilmiş ve yorumlanmıştır. Bu amaçla elde edilen veriler, önce sistematik ve açık bir biçimde betimlenmiş, daha sonra yapılan bu gözlemler, ses kaydına alınan veriler ve ölçekle alınan verilerle açıklanarak yorumlanmıştır.

Türkçe öğretmeni adaylarının hazırlıksız konuşmaları Ö1, Ö2, Ö3 ... şeklinde kodlanmıştır. Gözlemcilerin konuşma esnasında adaylara sorduğu sorular, başka bir deyişle gözlemcinin/gözlemcilerin konuşmaları ise $G 1, G 2$, G3 şeklinde kodlanmıştır.

\section{Geçerlik ve Güvenirlik} yapılmıştır.

$\mathrm{Bu}$ araştırmanın nicel ve nitel verilerine yönelik geçerlik ve güvenirlik çalışması ayrı ayrı 
Türkçe Öğretmeni Adaylarının Dinlediklerinden Hareketle Hazırlıksız Konuşma Başarıları: Karma Yöntem Araştırması

\section{Nicel Verilerin Geçerlik ve Güvenirliği}

"Konuşma Becerisi Derecelendirme Ölçeği"nin güvenirliği için Kendall's Tau Korelasyon Katsayısı hesaplanmıştır. Ölçekteki farklı testlerin madde iç tutarlılıklarının yüksek olduğu anlaşılmıştır. Bunun yanı sıra maddelerin iç tutarlılık güvenirliği de hesaplanmıştır. Ölçeğin söyleyiş testinin iç tutarlığı 0,87; akıcılığın iç tutarlıı̆̆ 0,86 ; dil yetkinliği testi maddelerinin iç tutarlılığı 0,84 ; etkileşimsunum testi maddelerinin iç tutarlııı puanı ise 0,90'dır. Ayrıca "Konuşma Becerisi Gözlem Formu" güvenirliği için de uzmanların katılımcılara verdiği puanların ortalaması hesaplanmıştır. Uzmanların katılımcılara verdiği puanların toplamları hesaplanarak karşslaştırılması yapılmıştır (Bkz. Tablo 1).

\section{Nitel Verilerin Geçerlik ve Güvenirliği}

Konuşma ve gözlem ölçeğinin yanı sıra farklı metin türleri Türkçe öğretmeni adaylarına dinletildikten sonra aynı konu ve tür üzerinde konuşması istenen Türkçe öğretmeni adaylarının konuşma metinlerinden güvenilir ve geçerli veri elde etmek amacıyla ses kaydı alınma yoluna gidilmiştir. Ses kaydına alınan veriler yazıya aktarılarak "Konuşma Becerisi Derecelendirme Ölçeği" doğrultusunda katılımcılara puanlama yapılmıştır. Bunun yanı sıra "Konuşma Becerisi Gözlem Formu"yla da katılımcıların hazırlıksız konuşmaları puanlandırılmışır. Araştırmada birden çok veri toplama aracıyla elde edilen verilerin karşılaştııılması ve araştırma bulgularının çeşitliliği, güvenirlik açısından önemli görülmektedir. Araştırmada çeşitlemenin amacı gerçeğin farklı yönlerinin ortaya konmasıdır. Üçgenleme olarak da adlandırılan çeşitleme, birden fazla araştırma aracının kullanıımasıdır (Yıldırım ve Şimşek, 2013; Birgin, 2016). Ayrıca araştırmanın güvenilirliğinin kontrol edilmesi amacıyla gözlemcilerin ortalama puanlarının Pearson Korelasyon ilişkisi hesaplanmıştır.

Tablo 2.

Gözlemciler Arası Uyum Katsayı Iliş̧kisini Gösteren Pearson Korelasyon ilişskisi

\begin{tabular}{llll}
\hline & 1.Gözlemci & 2.Gözlemci & 3.Gözlemci \\
\hline 1.Gözlemci & 1 & & \\
2.Gözlemci &, $998^{* *}$ & 1 & \\
3.Gözlemci &, $998^{* *}$ & $1,00^{* *}$ & 1 \\
\hline
\end{tabular}

Tablo 2 incelendiğinde gözlemciler arasındaki ilişkinin belirlenmesi için Pearson Korelasyon analizi sonucunda birinci gözlemci ve ikinci gözlemci arasında $(r=.998, p<.01)$; birinci gözlemci ve üçüncü gözlemci arasında $(r=.998, p<.01)$ ve son olarak ikinci gözlemci ve üçüncü gözlemci arasında $(r=1.00, p<.01)$ yüksek düzeyde pozitif yönlü anlamlı bir ilişki olduğu saptanmıştır. Büyüköztürk ve diğerlerine (2015) göre iyi düzeyde bir uyum, ölçme sonuçlarının güvenirliğini sağlar. Uzman incelemesi, nitel araştırmada verilerin eksikliği veya hatalarının tespit edilmesi açısından önemlidir (Yıldırım ve Şimşek, 2013). Araştırmanın veri toplama aracından elde edilen verilerin aynı sonucu verip vermediğini kontrol etmek amacıyla veriler üç araştırmacı tarafından ayrı ayrı analiz edilmiştir. Ayrıca nicel verilerin ortalamaları ve nitel verilerin ise ortak noktaları dikkate alınarak karşılaştırılmıştır.

\section{Bulgular ve Yorumlar}

Araştırmanın; "Türkçe öğretmeni adaylarının dinledikleri metinlerden hareketle yaptıkları hazırıksız konuşmalarındaki söyleyiş, akıcılık, dil yetkinliği ve etkileşim-sunum puanları arasında nasıl bir ilişki vardır?" şeklinde ifade edilen birinci sorusuna yönelik bulguları aşağıda verilmiştir.

Tablo 3.

Türkçe öğretmeni adaylarının söyleyiş, akıcılık, dil yetkinliği ve etkileşim-sunum ortalama puanları arasındaki ilişki

\begin{tabular}{lllll}
\hline & Söyleyiş & Akıcılık & Dil yetkinliği & Etkileşim-sunum \\
\hline Söyleyiş & 1 & & & \\
Akıcılık &, $857^{* *}$ & 1 & & \\
Dil yetkinliği &, $685^{* *}$ &, $688^{* *}$ & 1 & \\
\hline
\end{tabular}




\begin{tabular}{|c|c|c|c|c|}
\hline Etkil & $378^{*}$ & $432 * *$ & $671 * *$ & 1 \\
\hline
\end{tabular}

Türkçe öğretmeni adaylarının söyleyiş, akıcılık, dil yetkinliği ve etkileşim-sunum ortalama puanları arasında anlamlı bir ilişkinin olup olmadığı belirlemek için Pearson Korelasyon analizi yapılmıştır. Korelasyon katsayısının, 0.00-0.30 arasında olması, düşük düzeyi; 0.30-0.70 arasında olması, orta düzeyi; 0.70 ve üstü ise yüksek düzeyde bir ilişkinin olduğunu göstermektedir (Büyüköztürk, 2016). Analiz sonucunda söyleyiş ile akıcılık arasında pozitif yönde yüksek düzeyde anlamlı bir ilişki ( $r=.857, p<.01)$; olduğu bulunmuştur. Söyleyiş ile dil yetkinliği arasında pozitif yönde orta düzeyde anlamlı bir ilişki $(r=.685, p<.01)$; söyleyiş ile etkileşim-sunum arasında pozitif yönde orta düzeyde anlamlı bir ilişki $r=.378, p<.05)$; akıcılık ile dil yetkinliği arasında pozitif yönde orta düzeyde anlamlı bir ilişki ( $r=.688, p<.01)$; akıcılık ile etkileşim-sunum arasında pozitif yönde orta düzeyde anlamlı bir ilişki $(r=.432, p<.01)$; dil yetkinliği ile etkileşim-sunum arasında pozitif yönde orta düzeyde anlamlı bir ilişki olduğu $(r=.671, p<.01)$ bulunmuştur. Buna göre Türkçe öğretmeni adaylarının söyleyiş, akıcılık, dil yetkinliği ve etkileşim-sunum ortalama puanlarının birbiriyle ilişkili olduğu söylenebilir.

Araştırmanın; "Türkçe öğretmeni adaylarının dinledikleri metinlerden hareketle yaptıkları hazırlıksız konuşmaların eğilimi (zayıf-güçlü yönü) nasıldır?" şeklinde ifade edilen ikinci sorusuyla ilgili bulguları aşağıda verilmiştir:

Tablo 4.

Türkçe öğretmeni adaylarının konuşma ölçeğindeki söyleyişle ilgili maddelerden aldıkları puan ortalamaları ve başarı düzeyleri

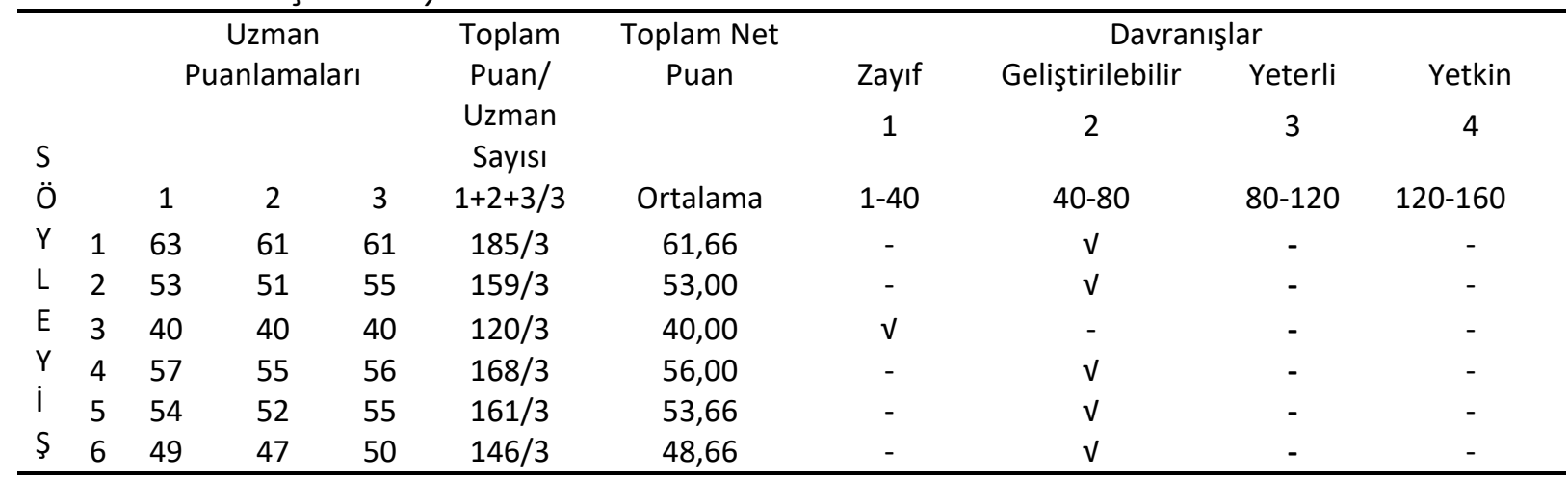

Tablo 4 incelendiğinde Türkçe öğretmeni adaylarının söyleyiş düzeyinin çoğunlukla "geliştirilebilir" (2) ve kısmen de "zayıf" (1) olduğu anlaşılmaktadır. Türkçe öğretmeni adaylarının söyleyiş düzeylerinin düşük olması adayların; sözcük seçimi, bağdaşıklık, tutarlılık, üstmetinsel ve söylemsel düzenlemede yeterli olmadığını göstermektedir.

Tablo 5.

Türkçe öğretmeni adaylarının gözlem formundaki söyleyişle ilgili maddelerden aldıkları puan ortalamaları ve başarı düzeyleri

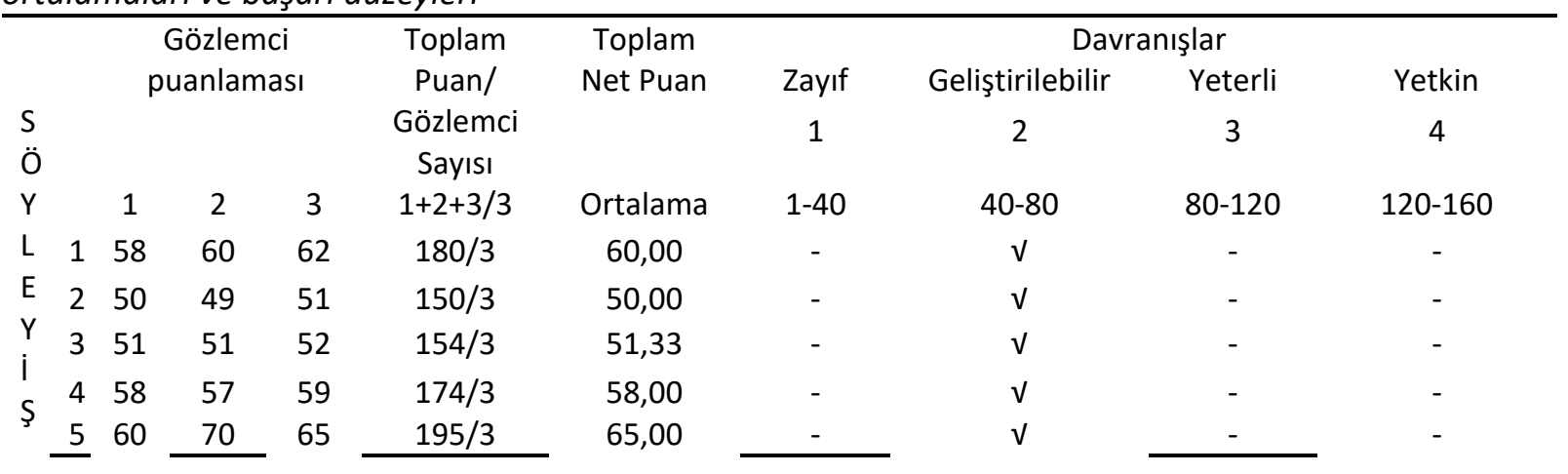


Türkçe Öğretmeni Adaylarının Dinlediklerinden Hareketle Hazırlıksız Konuşma Başarıları: Karma Yöntem Araştırması

\begin{tabular}{llllllllll} 
& 46 & 45 & 45 & $136 / 3$ & 45,33 & - & $v$ & - & - \\
7 & 46 & 55 & 56 & $157 / 3$ & 52,33 & - & $v$ & - & - \\
\hline
\end{tabular}

Tablo 5 incelendiğinde gözlem formunda söyleyişle ilgili verilerinin, konuşma derecelendirme ölçeğindeki verilerle paralellik gösterdiği anlaşıımaktır. Tablo 5'e göre Türkçe öğretmeni adaylarının söyleyişle ilgili düzeylerinin "geliştirilebilir" olduğu görülmektedir.

Konuşma ölçeği, gözlem formu ve Türkçe öğretmeni adaylarının sesten yazıya aktarılan metinleri dikkate alındığında, adayların konuşmalarında genel olarak ölçünlü dili kullansalar da zaman zaman bölgesel ve yerel dil kullandıkları da görülmüştür. Türkçe öğretmeni adaylarının hazırlıksız konuşmalarında her ne kadar ölçünlü dil kullanıldığı belirtilse de bu konuda istenilen düzeyde olmadıkları da anlaşımaktadır. Adayların hazırlıksız konuşmalarından alınan aşağıdaki örnekler, durumu açıklar niteliktedir.

Ö3: "Kurtla köpek açmış herhalde. Zaten günümüzde de bunu insanlara da çevirebiliriz. Insanlar da artık bu duruma geldi. Sadece hayvanlar için değil. Insanlar da en ufak bir şey için birbirini öldürebiliyor, savaşabiliyor. Yani bence burada yazarın vermek istediği mesaj hayvanlar üzerinden insanları kastedilmiştir."

Ö6: "Ya Dumlupınar Savaşını olayını anlatıyor. Dumlupınar Savaşını anlatıyor. Mustafa Kemal'in nasıl insanlara tepkisini falan. Tarihi bir şey yani. Insanların savaşa karşı nasıl mücadele ettiğini nasıl davranış tarzlarını falan ve tarihler falan var. Öyle savaşı anlatıyor."

Ö7: “...galiba böyle hikâye tarzında bir günlük anısını anlatmış sanki yazar. Hikâye tarzı bir anı anlatıyor yazar..."

Ö10: "Sağlığımız olmasa ne dışarı çıkabiliriz ne iş yerine gidebiliriz ne evlatlarımızla uğraşabiliriz, anne babamızla."

Ö16: "...dinlediğimiz metnin türü bir şiir öncelikle bunu bir kazanım olarak yani şiir olarak bir öğrenciye verebilmemiz gerektiğini düşünüyorum..."

Ö26: "...duygularından bahsetmiş. Kişilerin ne yaptıklarından falan bahsetmiş. Oturmuş kendi yaptıkları düşünceleri aktarmış."

Ö30: "Insanoğlunun araştırmacı olmasının üstünde duruyor. Çok eski zamanlara yani eski çağ dönemlerinde insanlar yeni yeni keşifler yapmışlardır. Tabii kademe kademe ilerlemişlerdir."

Türkçe öğretmeni adaylarının dinlediklerinden hareketle yaptıkları hazırlıksız konuşmalarında söyleyiş hususunda yeterli düzeyde olmadıkları anlaşılmaktadır. Söz konusu adayların ölçünlü dil kullanmak yerine yerel ve bölgesel dil kullandığı görülmektedir. Türkçe öğretmeni adaylarının ölçünlü dili kullanmadığına dair Ö3, Ö6, Ö7, Ö10, Ö16, Ö26 ve Ö30 kodlu adayların konuşmaları örnek olarak verilmiştir.

Tablo 6.

Türkçe öğretmeni adaylarının konuşma ölçeğindeki akıcılıkla ilgili maddelerden aldıkları puan ortalamaları ve başarı düzeyleri

\begin{tabular}{|c|c|c|c|c|c|c|c|c|c|}
\hline \multirow{2}{*}{$\begin{array}{l}A \\
K\end{array}$} & \multirow{2}{*}{\multicolumn{3}{|c|}{$\begin{array}{c}\text { Uzman } \\
\text { Puanlamaları }\end{array}$}} & \multirow{3}{*}{$\begin{array}{l}\text { Toplam } \\
\text { Puan/ } \\
\text { Uzman }\end{array}$} & \multirow{2}{*}{$\begin{array}{l}\text { Toplam } \\
\text { Net Puan }\end{array}$} & \multicolumn{4}{|c|}{ Davranışlar } \\
\hline & & & & & & Zayıf & Geliştirilebilir & Yeterli & Yetkin \\
\hline I & & & & & & 1 & 2 & 3 & 4 \\
\hline C & & & & Sayısı & & & & & \\
\hline I & 1 & 2 & 3 & $3 / 3$ & Ortalama & $1-40$ & $40-80$ & $80-120$ & 120160 \\
\hline L 7 & 54 & 45 & 66 & $165 / 3$ & 55,00 & - & v & - & - \\
\hline 18 & 48 & 54 & 69 & $171 / 3$ & 57,00 & - & v & - & - \\
\hline K 9 & 45 & 49 & 52 & $146 / 3$ & 48,66 & - & v & - & - \\
\hline 10 & 58 & 65 & 70 & $193 / 3$ & 64,33 & - & $\sqrt{ }$ & - & - \\
\hline
\end{tabular}

Tablo 6 incelendiğinde Türkçe öğretmeni adaylarının hazırlıksız konuşmalarındaki akıcılık düzeyinin "geliştirilebilir" olduğu anlaşımaktadır. Konuşma ölçeği ve gözlem formundan elde edilen verilerin yanı sıra Türkçe öğretmeni adaylarının sesten yazıya aktarılmış konuşmalarında da aynı 
doğrultuda verilere ulaşımıştır. Adayların, hazırlıksız konuşmaları esnasında "ıIı", "eeee" vb. asalak seslere ve beklemelere yer verdiği ve çoğu zaman cümlelerde gereksiz sözcükler kullandığı anlaşılmıştır. Türkçe öğretmeni adaylarının hazırlıksız konuşmalarından hareketle verilen örnekler bu durumu açıklar niteliktedir.

Tablo 7.

Türkçe öğretmeni adaylarının gözlem formundaki akıcılıkla ilgili maddelerden aldıkları puan ortalamaları ve başarı düzeyleri

\begin{tabular}{|c|c|c|c|c|c|c|c|c|c|c|}
\hline \multirow[b]{2}{*}{ A } & & \multirow{2}{*}{\multicolumn{3}{|c|}{$\begin{array}{c}\text { Gözlemci } \\
\text { puanlaması }\end{array}$}} & \multirow{2}{*}{$\begin{array}{l}\text { Toplam } \\
\text { Puan/ }\end{array}$} & \multirow{2}{*}{$\begin{array}{l}\text { Toplam } \\
\text { Net Puan }\end{array}$} & \multicolumn{4}{|c|}{ Davranışlar } \\
\hline & & & & & & & Zayıf & Geliştirilebilir & Yeterli & Yetkin \\
\hline K & & & & & Gözlemci & & 1 & 2 & 3 & 4 \\
\hline I & & & & & Sayısı & & & & & \\
\hline C & & 1 & 2 & 3 & $1+2+3 / 3$ & Ortalama & $1-40$ & $40-80$ & $80-120$ & $120-160$ \\
\hline I & 8 & 56 & 65 & 60 & $181 / 3$ & 60,33 & - & $\sqrt{ }$ & - & - \\
\hline L & 9 & 40 & 40 & 40 & $120 / 3$ & 40,00 & $\sqrt{ }$ & - & - & - \\
\hline 1 & 10 & 40 & 40 & 40 & $120 / 3$ & 40,00 & V & - & - & - \\
\hline$K$ & 11 & 53 & 51 & 48 & $152 / 3$ & 50,66 & - & $\sqrt{ }$ & - & - \\
\hline
\end{tabular}

Tablo 7 incelendiğinde Türkçe öğretmeni adaylarının akıcılıkta "zayıf" ve "geliştirilebilir" düzeyde olduğu anlaşılmaktadır. Akıcılıkla ilgili en yüksek ortalama 60,33; en düşük ortalama ise 40'tır.

Ö2: "... burada ben mesela çocuklardan ben yola çıkmak istiyorum. Çocuklar özellikle bir oyuncak veya herhangi bir nesne olabilir, bunu kendilerine arkadaş edinebiliyorlar ve onun dünyasına açılabiliyorlar. Eee... III... burda da mesela bir çocuk düşünelim. Onun uçurtmanın sadece bir uçurtma, gökyüzüne uçurduğu bir oyuncak değil, onun için neler ifade ettiği, hani ne kadar önemli olduğu onu arkadaş gibi gördügü aslında anlatılmaya çalışılmıştır."

Ö11: "Anne ve babanın çocuk üzerindeki etkisinden bahsediliyor. Sadece anne ve babanın etkisi de değil öğretmen ve çevrenin etkisinden de bahsediliyor. Çocuk için yapılan fedakârlıklar falan çocuğun uyum sağlanabilmesi için yaşadığı sıkıntılara destek olmak için anne ve babanın etkisinden bahsediliyor."

Ö19: "...ayrıyetten ordan bağlantı yaparsınız...."

Ö23: "....ıIIIII hani aslında böyle bir hikaye var ama çok da Ağustos böceği haklı değil ya da haksız değil. Karıncanın çalışkan olarak bir yerlere vardığını söylemiyor. Insanlar çalışmadan da belki hayatını devam ettirebilir. Hayati devam ettirmek için tek şey çalışmak değil."

Türkçe öğretmeni adaylarının dinlediklerinden hareketle yaptıkları konuşmalar incelendiğinde adayların cümlelerin çoğunda gereksiz sözcüklere, gereksiz yinelemelere, "IIIı", "eee" gibi asalak seslere, beklemelere yer verdiği, dolayısıyla akıcılı̆ıın sağlanamadığı anlaşıımaktadır. Örneğin, Ö2, Ö11, Ö19 ve Ö23 kodlu Türkçe öğretmeni adaylarının konuşmalarında söz konusu sorunlar bulunmaktadır. Bunun başlıca nedenlerinden biri öğretmen adaylarının sözcük dağarcı̆ı̆ın yetersiz olması ve planlı konuşma alışkanlığının olmamasıdır.

Tablo 8.

Türkçe öğretmeni adaylarının konuşma ölçeğindeki dil yetkinliğiyle ilgili maddelerden aldıkları puan ortalamaları ve başarı düzeyleri

\begin{tabular}{|c|c|c|c|c|c|c|c|c|c|c|}
\hline \multirow[t]{2}{*}{ D } & & \multicolumn{3}{|c|}{ Uzman } & Toplam & Toplam & \multicolumn{4}{|c|}{ Davranışlar } \\
\hline & & \multicolumn{3}{|c|}{ Puanlamaları } & Puan/ & Net Puan & Zayıf & Geliştirilebilir & Yeterli & Yetkin \\
\hline $\begin{array}{l}\mathrm{T} \\
\mathrm{T}\end{array}$ & & & & & $\begin{array}{l}\text { Uzman } \\
\text { Sayısı }\end{array}$ & & 1 & 2 & 3 & 4 \\
\hline $\begin{array}{l}k \\
i\end{array}$ & & 1 & 2 & 3 & $3 / 3$ & Ortalama & $1-40$ & $40-80$ & $80-120$ & $120-160$ \\
\hline $\mathrm{N}$ & 11 & 55 & 60 & 58 & $173 / 3$ & 57,66 & - & v & - & - \\
\hline 1 & 12 & 44 & 56 & 53 & $153 / 3$ & 51,00 & - & V & - & - \\
\hline & 13 & 45 & 40 & 49 & $134 / 3$ & 44,66 & - & v & - & - \\
\hline
\end{tabular}


Türkçe Öğretmeni Adaylarının Dinlediklerinden Hareketle Hazırlıksız Konuşma Başarıları: Karma Yöntem Araştırması

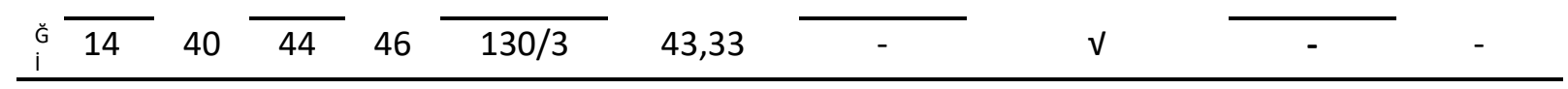

Tablo 8 incelendiğinde Türkçe öğretmeni adaylarının dinlediklerinden hareketle hazırlıksız konuşmalarında dili yetkin bir şekilde kullanmadıkları anlaşılmaktadır. Tablo 8'e göre söz konusu adayların dil yetkinliği bağlamında "geliştirilebilir" düzeyde olduğu anlaşılmaktadır. Dil yetkinliğiyle ilgili Türkçe öğretmeni adaylarının en düşük ortalama puan 43,33; en yüksek ortalama puan ise 57,66'dır. Düşük ortalamaya sahip olan madde, üstmetinsel ve söylemsel düzenlemeyle ilgilidir. En yüksek ortalamaya sahip madde ise sözcükler ve sözcüklerin amacına bağlı olarak kullanılmasıyla ilişkilidir.

Tablo 9.

Türkçe öğretmeni adaylarının gözlem formundaki içerik-dil kullanımıyla ilgili maddelerden aldığı puan ortalamaları ve başarı düzeyleri

\begin{tabular}{|c|c|c|c|c|c|c|c|c|c|c|}
\hline \multirow[b]{2}{*}{ i } & & \multirow{2}{*}{\multicolumn{3}{|c|}{$\begin{array}{l}\text { Gözlemci } \\
\text { puanlaması }\end{array}$}} & \multirow{3}{*}{$\begin{array}{c}\text { Toplam } \\
\text { Puan/ } \\
\text { Gözlemc }\end{array}$} & \multirow{2}{*}{$\begin{array}{l}\text { Toplam } \\
\text { Net Puan }\end{array}$} & \multicolumn{4}{|c|}{ Davranışlar } \\
\hline & & & & & & & Zayıf & Geliştirilebilir & Yeterli & Yetkin \\
\hline $\mathrm{R}$ & & & & & & & 1 & 2 & 3 & 4 \\
\hline$i$ & & & & & i Sayısı & & & & & \\
\hline $\begin{array}{l}K \\
D\end{array}$ & & 1 & 2 & 3 & $3 / 3$ & Ortalama & $1-40$ & $40-80$ & $80-120$ & $120-160$ \\
\hline $\mathrm{i}$ & 12 & 57 & 45 & 40 & $142 / 3$ & 47,33 & - & v & - & - \\
\hline $\mathrm{L}$ & 13 & 45 & 52 & 47 & $144 / 3$ & 48,00 & - & v & - & - \\
\hline K & 14 & 38 & 46 & 55 & $139 / 3$ & 46,33 & - & V & - & - \\
\hline L & 15 & 38 & 54 & 48 & $140 / 3$ & 46,66 & - & $\mathrm{V}$ & - & - \\
\hline $\begin{array}{l}\mathrm{L} \\
\mathrm{A}\end{array}$ & 16 & 64 & 58 & 63 & $185 / 3$ & 61,66 & - & $\mathrm{v}$ & - & - \\
\hline $\mathrm{N}$ & 17 & 40 & 40 & 40 & $120 / 3$ & 40,00 & $\mathrm{v}$ & - & - & - \\
\hline M & 18 & 40 & 40 & 40 & $120 / 3$ & 40,00 & $\mathrm{v}$ & - & - & - \\
\hline 1 & 19 & 46 & 47 & 50 & $143 / 3$ & 47,66 & - & $\mathrm{v}$ & - & - \\
\hline
\end{tabular}

Tablo 9 incelendiğinde gözlem formundan elde edilen içerik-dil kullanımı başarı puanlarının ortalaması ile konuşma ölçeğinden elde edilen puanların ortalamalarının birbirine yakın olduğu anlaşılmaktır. Tablo 9'a göre Türkçe öğretmeni adaylarının dinlediklerinden hareketle yaptıkları hazırıksız konuşmalarında dil kullanımı başarıları çoğunlukla "geliştirilebilir" düzeydedir.

Türkçe öğretmeni adayları, dinlediklerinden hareketle yaptıkları hazırlıksız konuşmalarında dili üstmetinsel ve söylemsel düzeyde kullanmada yetersiz kalmışlardır. Adayların içerik dil kullanımı maddelerinden aldığı en düşük ortalama 40 , en yüksek ortalama ise $61,66^{\prime}$ dır. Türkçe öğretmeni adaylarının dinlediklerinden hareketle gerçekleştirdikleri hazırlıksız konuşma cümlelerinin ve/veya metinlerinin daha çok günlük konuşma diline yakın olduğu ve söz konusu adayların dili söylemsel işlevde kullanamadıkları anlaşılmıştır. Aşağıda adayların hazırıısız konuşmalarından hareketle verilen doğrudan alıntılar durumu açıklar niteliktedir:

Ö1: "Bunun dışında iyilik yapmanın önemli bir kavram olduğundan ve elindeki şeyleri paylaşmanın güzel olduğu anlatılıyor. Paylaşım yapmak da insanların en önemli ihtiyacıdır. Insanlar elindekini avucundaki yeri geldiği zaman paylaşabilmeli yaşamlarının farkında olabilmeliler."

Ö2: "Şiir ile bağlantısı da şiir genelde duygu, düşünceleri anlatan bir tür olduğu için, mesela biz bu şekilde duygularımızın özellikle yoğun olduğu konularda, arkadaşlık mesela, her türlü duyguyu içeren bir kavram."

Ö10: "Sağlığın sporla ilişkisini açıklamış. Hem eklemlerimize hem uyku düzenimize hem beslenmemize nasıl etki ettiğini açıklamış. Spor her anlamda hem hayatın kalitesini artırmada hem arkadaşlarımızla ilişkilerimizde ne kadar önemli bir rol olduğunu gösteriyor bize."

Ö14: "Çocuk dediğimizde aklımıza ilk gelen şey oyundur, oyunla bütünleşmişlerdir. Çocuklar oyun sayesinde sorumluluk bilinci alırlar."

Ö16: "Merhaba arkadaşlar bu dinlediğimiz metnin türü bir şiir öncelikle bunu bir kazanım olarak yani şiir olarak bir öğrenciye verebilmemiz gerektiğini düşünüyorum." 
Ö17: "Mesela denizin temizliğini anlatıyor. Oranın yapılarından, yapıların sağlamlığından bahsetmiştir. Tarihi yapılarından bahsetmektedir. Türü gezi yazısıdır. Gezi yazısı olarak da bilgilendirici metin tarzında verilmiş bir metindir."

Ö25: "Efsaneler gerçeğe yakın olayları anlatan türdür. Bu şekilde efsaneler destandan ayrılırlar. Efsanelerde daha çok olağanüstülükler anlatılır. Bu şekilde ben biraz türe değindim. Şimdi yoruma geçiyorum. Burada yazar anlatım olarak çok süslü kelimeler kullanmış. Bu metinde şunu anlatmış herhalde bir tane kızın hayatı sorunu ve derdi."

Ö1, Ö2, Ö10, Ö14, Ö16, Ö17 ve Ö25 kodlu Türkçe öğretmeni adaylarının konuşmalarından alınan kesitler incelendiğinde adayların dil yetkinliği, dil kullanımı konusunda yeterli düzeyde olmadığı anlaşılmaktadır. Örneğin Ö1 kodlu adayın; "Paylaşım yapmak da insanların en önemli ihtiyacıdır." cümlesindeki "paylaşmak" yerine "paylaşım yapmak"; Ö10 kodlu adayın; "...açıklamış" ... "açıklamış" yüklemlerini art arda kullanması ve Ö16 kodlu adayın; "...dinlediğimiz metnin türü bir şiir öncelikle bunu bir kazanım olarak yani şiir olarak bir öğrenciye..." cümlesindeki mantıksal ve anlamsal bağların zayıf olması, durumu örneklendiren birkaç cümledir. Türkçe öğretmeni adaylarının dinlediklerinden hareketle yaptıkları hazırlıksız konuşmalarda dil yetkinliğinin zayıf olduğuyla ilgili verilen Ö2, Ö14, Ö17 ve Ö25 kodlu adayların konuşmalarında da benzer durumlar göze çarpmaktadır.

Tablo 10.

Türkçe öğretmeni adaylarının konuşma ölçeğindeki etkileşim-sunumla ilgili maddelerden aldıkları puan ortalamaları ve başarı düzeyleri

\begin{tabular}{|c|c|c|c|c|c|c|c|c|c|c|}
\hline \multirow[b]{2}{*}{$\mathrm{E}$} & & \multicolumn{3}{|c|}{ Uzman } & Toplam & Toplam & \multicolumn{4}{|c|}{ Davranışlar } \\
\hline & & Pua & lamala & & Puan/ & Net Puan & Zayıf & Geliştirilebilir & Yeterli & Yetkin \\
\hline $\mathrm{T}$ & & & & & Uzman & & 1 & 2 & 3 & 4 \\
\hline K & & & & & Sayısı & & & & & \\
\hline i & & 1 & 2 & 3 & $3 / 3$ & Ortalama & $1-40$ & $40-80$ & $80-120$ & $120-160$ \\
\hline L & 15 & 54 & 52 & 53 & $159 / 3$ & 53,00 & - & v & - & - \\
\hline $\mathrm{E}$ & 16 & 40 & 40 & 40 & $120 / 3$ & 40,00 & V & - & - & - \\
\hline Ş & 17 & 59 & 62 & 68 & $189 / 3$ & 63,00 & - & v & - & - \\
\hline i & 18 & 46 & 45 & 48 & $139 / 3$ & 46,33 & - & $v$ & - & - \\
\hline M & 19 & 54 & 53 & 55 & $162 / 3$ & 54,00 & - & v & - & - \\
\hline- & 20 & 50 & 49 & 48 & $147 / 3$ & 49,00 & - & v & - & - \\
\hline$S$ & 21 & 82 & 80 & 81 & $243 / 3$ & 80,00 & - & - & v & - \\
\hline U & 22 & 82 & 79 & 81 & $242 / 3$ & 80,66 & - & - & v & - \\
\hline $\mathrm{N}$ & 23 & 49 & 47 & 51 & $147 / 3$ & 49,00 & - & v & - & - \\
\hline U & 24 & 52 & 50 & 48 & $150 / 3$ & 50,00 & & v & - & - \\
\hline M & 25 & 48 & 46 & 53 & $147 / 3$ & 49,00 & - & $v$ & - & - \\
\hline & 26 & 49 & 47 & 48 & $144 / 3$ & 48,00 & - & v & - & - \\
\hline & 27 & 53 & 51 & 55 & $159 / 3$ & 53,00 & - & v & - & - \\
\hline
\end{tabular}

Tablo 10 incelendiğinde Türkçe öğretmeni adaylarının dinlediklerinden hareketle hazırlıksız konuşmalarında etkileşim-sunum becerisinde çoğunlukla "geliştirilebilir" düzeyde olduğu anlaşılmaktadır. Tablo 10'a göre Türkçe öğretmeni adaylarının etkileşim-sunumla ilgili maddelerden aldıkları en düşük ortalama 40 , en yüksek ortalama ise $80.66^{\prime}$ dır.

Tablo 11.

Türkçe öğretmeni adaylarının gözlem formundaki etkileşim-sunum stratejileriyle ilgili maddelerden aldığı puan ortalamaları ve başarı düzeyleri

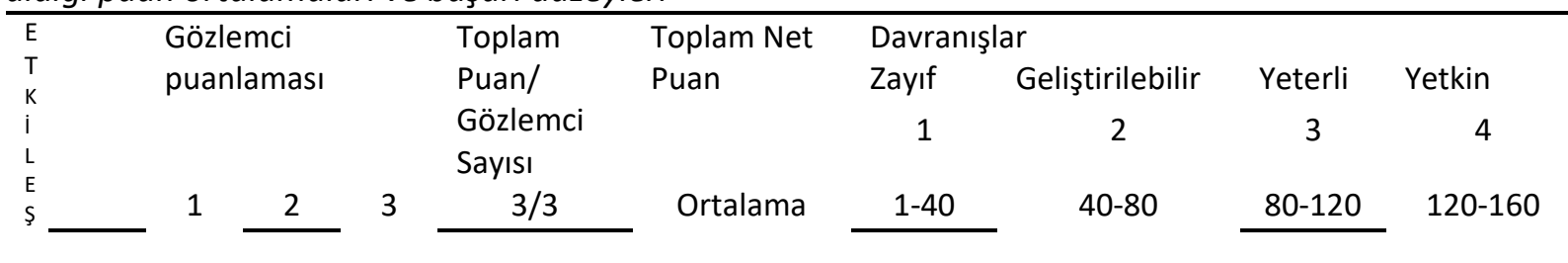


Türkçe Öğretmeni Adaylarının Dinlediklerinden Hareketle Hazırlıksız Konuşma Başarıları: Karma Yöntem Araştırması

\begin{tabular}{|c|c|c|c|c|c|c|c|c|c|c|}
\hline i & 20 & 44 & 50 & 53 & $147 / 3$ & 49,00 & - & $\mathbf{v}$ & - & - \\
\hline $\begin{array}{l}\text { IV } \\
S\end{array}$ & 21 & 35 & 40 & 45 & $120 / 3$ & 40,00 & V & - & - & - \\
\hline $\mathrm{T}$ & 22 & 65 & 59 & 70 & $194 / 3$ & 64,66 & - & $\mathrm{V}$ & - & - \\
\hline $\begin{array}{l}R \\
A\end{array}$ & 23 & 75 & 67 & 65 & $207 / 3$ & 69,00 & - & $\mathrm{V}$ & - & - \\
\hline $\mathrm{T}$ & 24 & 65 & 71 & 69 & $205 / 3$ & 68,33 & - & $\mathrm{V}$ & - & - \\
\hline $\begin{array}{l}E \\
J\end{array}$ & 25 & 56 & 49 & 41 & $146 / 3$ & 48,66 & - & V & - & - \\
\hline i & 26 & 45 & 55 & 60 & $160 / 3$ & 53,33 & - & V & - & - \\
\hline $\begin{array}{l}\mathrm{L} \\
\mathrm{E}\end{array}$ & 27 & 56 & 49 & 43 & $148 / 3$ & 49,33 & - & $\mathrm{V}$ & - & - \\
\hline $\mathrm{R}$ & 28 & 47 & 46 & 54 & $147 / 3$ & 49,00 & - & $\mathrm{V}$ & - & - \\
\hline i & 29 & 48 & 52 & 46 & $146 / 3$ & 48,66 & & $\mathrm{~V}$ & - & - \\
\hline & 30 & 53 & 46 & 51 & $150 / 3$ & 50,00 & - & $\mathrm{V}$ & - & - \\
\hline
\end{tabular}

Tablo 11 incelendiğinde gözlem formundan elde edilen etkileşim-sunum stratejileri maddelerinin puan ortalamaları ile konuşma ölçeğinden elde edilen puanların ortalamalarının birbirine yakın olduğu anlaşılmaktır. Tabloya göre Türkçe öğretmeni adaylarının dinlediklerinden hareketle hazırlıksız konuşmalarında etkileşim-sunum stratejilerinin başarısı çoğunlukla "geliştirilebilir" düzeydedir. Söz konusu adayların etkileşim-sunum stratejileri maddelerinden aldığı puan ortalamalarının en düşüğü 40 , en yükseği ise $69^{\prime}$ dur. Türkçe öğretmeni adaylarının dinlediklerinden hareketle gerçekleştirdikleri hazırlıksız konuşmalarında soruya uygun cevap verme ve tartışma sırasında söylem oluşturabilme becerisinin zayıf olduğu anlaşılmıştır. Aşağıda Türkçe öğretmeni adaylarının hazırlıksız konuşmalarından hareketle verilen doğrudan alıntılar durumu açıklar niteliktedir:

G1: "Dinlediğin metnin türü ne olabilir, destan mı, tiyatro mu?"

Ö19: "Vatan Yahut Siliste destan da var, ayrıyetten ordan bağlantı yaparsınız."

G1: "Metnin türünün hikâye olduğunu düşünerek tür-metin ilişkisini nasıl kurabilirsin?"

Ö12: "Hocam burada mesela postacı ile kadın arasında bir şey anlatıldığı için hikâye türüne giriyor."

G2: "Dinlediğin metnin türü nedir?"

Ö28: "Şiir ya da deneme olabilir... Deneme, karşıdakine sohbet havası taşıyacak şekilde düşüncelerin aktarılmasına denilir. Bu metinde ise bir çocuğun duygularını resme aktarıyor. Doğadaki huzuru resme aktariyor."

G3: Şiirin başlığı "Kilim" olduğu için "şiir ile kilim" arasında nasıl bir ilişki kurabilirsin?

Ö31: "Aslında ikisi de aynı. Şiir üzerinde yazılmış bir kilim. Soyutlamaya gidilmiş. Şiirde duygu ve düşüncelerini dokuyor diyebiliriz. Şiir duygu ve düşüncelerimizi mesela bu bir aşk olabilir, sevgi olabilir kâğıda aktarmaktır. Burada da kilim üzerinden verilmiş bir mesaj vardır. Bu; sevgi, aşk, özlem, hasrettir."

Türkçe öğretmeni adaylarının dinlediklerinden hareketle yaptıkları konuşmaları incelendiğinde söz konusu adayların etkileşim-sunum becerisinde zayıf düzeyde olduğu anlaşılmaktadır. Örneğin, gözlemci ile öğretmen adayı arasında geçen G1: "Dinlediğin metnin türü ne olabilir, destan mı, tiyatro mu?" ve Ö19: "Vatan Yahut Siliste destan da var, ayrıyetten ordan bağlantı yaparsınız." şeklindeki diyalog Türkçe öğretmeni adaylarının tartışma sırasında söylem oluşturmadığı, soru-yanıt ve tartışma sırasında uygun cevap vermediği, konuya hâkim bir şekilde konuşamadığını ortaya koymaktadır.

Araştırmanın; "Türkçe öğretmeni adaylarının dinlediklerinden hareketle yaptıkları hazırlıksız konuşmalarında karşılaşılan sorunlar nelerdir?" şeklinde ifade edilen üçüncü sorusuna ilişkin bulguları aşağıda verilmiştir.

Tablo 12.

Türkçe öğretmeni adaylarının dinlediklerinden hareketle hazırlıksız konuşma sorunları

Sorunlar

Dinledikleri tür ile metni ilişkilendirememe

Dinlediklerini olduğu gibi özetleme, kendisine özgü üslup oluşturamama 
Konuşmayı doğal ve canlı bir şekilde ifade edememe

Konuşmanın çoğu yerinde gereksiz yinelemelere yer verme

Konuşmada deyim, imge, atasözü vb. unsurlara başvurmama

Konuşmada düşünceyi geliştirme unsurlarına yer vermeme

Sorulan soruya uygun cevap verememe ve tartışmaya girememe

Bürünsel (prozodik) unsurları doğru kullanamama

Cümleler arasında mantıksal ve anlamsal bağlantıları yapamama

Tablo 4, 5, 6, 7, 8, 9, 10 ve 11 incelendiğinde Türkçe öğretmeni adaylarının dinlediklerinden hareketle hazırlıksız konuşmalarının düzey olarak yeterli olmadığı yönünde istatistiksel verilere ulaşılmıştır. Tablo 12 incelendiğinde ise Türkçe öğretmeni adaylarının dinlediklerinden hareketle yaptıkları hazırlıksız konuşmalarında dili yetkin bir şekilde kullanmayla ilişkili konularda sorunlar yaşadığı anlaşılmaktadır. Türkçe öğretmeni adaylarının dinlediklerinden hareketle hazırlıksız konuşmalarında yaşadıkları bu sorunlarla ilgili bazı hazırlıksız konuşma örnekleri şöyledir:

Ö2: "Burda da mesela bir çocuk düşünelim. Onun uçurtmanın sadece bir uçurtma, gökyüzüne uçurduğu bir oyuncak değil, onun için neler ifade ettiği, hani ne kadar önemli olduğu onu arkadaş gibi gördügü aslında anlatılmaya çalışılmıştır. Şiir ile bağlantısı da şiir genelde duygu, düşünceleri anlatan bir tür olduğu için, mesela biz bu şekilde duygularımızın özellikle yoğun olduğu konularda, arkadaşlık mesela, her türlü duyguyu içeren bir kavram."

Ö6: "Ya Dumlupınar Savaşını olayını anlatıyor. Dumlupınar Savaşını anlatıyor. Mustafa Kemal' in nasıl insanlara tepkisini falan. Tarihi bir şey yani. Insanların savaşa karşı nasıl mücadele ettiğini nasıl davranış tarzlarını falan ve tarihler falan var. Öyle savaşı anlatıyor."

Ö9: "Burada kurdun bir insandan yardım dilemesini anlatıyor ve başılıla ilişkilendirdiğim zaman, "iyiliğin değerini bilen kim" büyük ihtimalle sonu kötü olacak yani kurt ve o insan arasındaki ilişki kötü bir şekilde sonuçlanacak."

Ö21: "Bu metinde sosyal medyanın psikoloji üzerindeki etkisinden bahsediyor. Çağımızın en büyük sorunlarından biri sizin de bildiğiniz gibi sosyal medyadır. Sosyal medya insanlara bir yarış getirdi, bir beğenilme yarışı. iki insan aynı anda sosyal medyaya birer fotoğraf atıyorlar sonra beklemeye başlıyorlar."

Ö24: "Şiirde şair dışarı çıkıyor ve kırlarda çiçekler gördüm, çiçeklerin üstüne konan arılar gördüm diyor. Peteklerdeki baldan bahsedilmiş. Eski çarşıda olan demircilerden bahsedilmiştir."

Ö27: "Burada Çanakkale Savaşın sırasındaki hepimizin bildiği Seyit Onbaşı'ndan bahsediliyor. Seyit Onbaşı'nı zaten işte bir gülleyi tek başına yüklemesi, hani hepimiz o şekilde tanıyoruz biliyoruz."

Ö30: "Şimdi burada insanoğlunun keşif yani sürekli doğayla iç içe olup da başka şeyleri arama çabalarına girmelerinden bahsediyor. Metinden de anlaşılacağı gibi insanoğlu elinde olan şeylerin daha ilerisini daha iyisini keşfetme yollarını bulmaya çalışmışlardır."

\section{Tartışma, Sonuç ve Öneriler}

Dinleme becerisi/eğitimi ve bu beceriyle ilişkili yapılmış araştırmalar (Aşılıoğlu, 2009; Aytan, 2011; Ceran, 2015; Ceyran, 2016; Çifçi, 2001; Doğan, 2007; Doğan, 2008; Durukan ve Maden, 2010; Epçaçan, 2013; Karadüz, 2010; Karatay, Dolunay ve Savaş, 2014; Karagündüz, 2010, Kemiksiz, 2015; Kurudayıoğlu ve Savaş, 2020; Kurudayıoğlu ve Kiraz, 2020; Maden ve Durukan, 2011; Melanlıoğlu, 2012a; Melanlıoğlu, 2012b; Özbay ve Çetin 2011; Sevim ve Kaya, 2016; Şahin, 2011; Şahin ve Aydın, 2009; Temur, 2010; Tüzel 2013; Tüzel ve Keleş, 2013; Yazıcı ve Kurudayıoğlu, 2017) ile konuşma becerisi/eğitimi ve bu beceriyle ilgili yapıımış araştırmalar (Bayburtlu, 2019; Bulut, 2015; Bulut, Açık ve Çiftçi, 2016; Bozkurt, 2017; Bozkurt ve Arıca-Akkök, 2019; Çintaş-Yıldız ve Yavuz, 2012; Doğan, 2009; Erdem ve Erdem 2015; Gürhan, 2013; Kartallıoğlu, 2018; Kurudayığlu, 2003; Maden, 2011; Orhan, Kırbaş ve Topal, 2012; Öztürk, 1997; Sallabaş, 2011; Sargın 2006; Sevim, 2012; Temizkan, 2009; Temizkan ve Atasoy, 2016; Yüceer, 2014) incelendiğinde dinleme ve konuşma becerisinin diğer becerileri etkileyecek, önemsenmesi gereken beceriler olduğu ve bu iki becerinin farklı değişkenlere 
göre incelenebileceği anlaşımaktadır. Her iki becerinin farklı bir yönünün ön plana çıktığı araştırmaların sonuçları dikkate alınarak dinleme ve konuşmanın birbirinden ayrılmaz bir bütün olduğu da göz önünde bulundurulmak suretiyle bu araştırmada, Türkçe öğretmeni adaylarının dinlediklerinden hareketle hazırlıksız konuşma başarılarının zayıf-güçlü yönleri tespit edilmiştir.

İnsanlar günlük hayatta sürekli dinleme ve konuşma halindedir. Konuşma ve dinleme birbirini tamamlayan ve birbirinden ayrı düşünülmeyen, biri alıcı diğeri ise verici niteliğindeki anlatma ve anlama becerileridir (Temizyürek, Erdem ve Temizkan, 2014). Konuşma ve dinleme becerilerinin birbirinden ayrılmaz iki beceri olduğu düşünülerek Türkçe öğretmeni adaylarının dinlediklerinden hareketle yaptıkları hazırıksız konuşma başarılarının zayıf-güçlü yönlerinin belirlenmeye çalışıldığı bu araştırmada, söz konusu adayların hazırlıksız konuşmalarında; söyleyiş, akıcılık, dili yetkin kullanma ve etkileşim gibi yönlerden zayıf oldukları sonucuna ulaşılmıştır.

Akkaya (2012) yaptığı araştırmada öğretmen adaylarındaki konuşma sorunlarının çoğunlukla "ses, ton, vurgu, telaffuz yanlışları" olduğu sonucuna ulaşmıştır. Bu araştırma sonucuna göre de Türkçe öğretmeni adaylarının prozodik unsurları kullanmada zayıf olduğu tespit edilmiştir. Ancak söz konusu adayların önemli konuşma sorunlarının; dili yetkin bir şekilde kullanmama, duygu ve düşünceleri mantıklı bir şekilde ifade etmeme, konuşmada deyim, atasözü, düşünceyi geliştirme yollarına başvurmama olduğu anlaşılmışır. Güneş, (2016: 215) Türkçe Dersi Öğretim Programı'nda "metin üretimi ve metin üretme modelleri" vb. becerilerin yer almadığını belirtmiştir. Ayrıca Şahin ve Aydın (2009: 455)'a göre "anlama kavramı büyük ölçüde dinleme becerisiyle ilişkilidir." Araştırmada elde edilen sonuçlara göre Türkçe öğretmeni adaylarının dinlediklerinden hareketle; üstmetinsel düzenlemede, söylem oluşturmada yetersiz olduğu ve dinlediklerini anlamlandırmada sorunlar yaşadığı anlaşılmıştır. Bütün bunlar, konuşucunun, konuşmacının bürünsel unsurları doğru şekilde kullanmamasıyla ilişkilidir. Bürünsel unsurlar anlamın belirlemesinde de etkilidir. "Dilde "parçalar üstü" ya da "bürünsel" olarak adlandırılan vurgu, ezgi, tonlama gibi ögelerin anlama önemli katkıları vardır. Bu ögeler iyi kullanıldıkları zaman dış yapıyı etkiledikleri kadar içyapıyı da etkileyebilirler" (Börekçi, 2005: 205). Bu açıklamalar dikkate alındığında vurgu, tonlama vb. unsurların anlamı da belirlediği ortaya çıkmaktadır.

Türkçe öğretmeni adayları, dinlediklerini kendi üsluplarıyla kurgulayıp yeni cümlelerle ifade etmek yerine dinledikleri metinleri özetleme yoluna gitmişlerdir. Bu durum Türkçe öğretmeni adaylarının, anladıklarını kendi üsluplarıyla ifade edemediklerini göstermektedir.

Dinleme ve konuşma birbirinden ayrımaz iki dil becerisi olduğu gibi konuşma ve yazma da duygu ve düşüncelerin anlatımı açısından birbirine yakın iki beceridir. Biri duygu ve düşünceleri sözlü, diğeri ise yazılı olarak ifade etme olanağını sunmaktadır. Aydın (2014: 176)'a göre öğrencilerin "...fikirlerini destekleyecek örneklere yer verememeleri" ve "konulara tek yönlü bakılmakta olması, farklı bakışlarının olmaması" Türkçe öğretiminde görülen sorunlar olarak açıklanmıştır. Konuşma sürecinde dinleme, dinleme sürecinde anlama gerçekleşir. Dinleme/anlama sürecinde ise duygu ve düşünceler sözlü veya yazılı olarak ifade edilir. Bu durum, dinleme becerisinin, konuşma ve yazma becerisiyle ilişkili olduğunu göstermektedir (Özbay, 2014). Araştırmanın sonucuna göre Türkçe öğretmeni adaylarının dinlediklerinden hareketle yaptıkları hazırıksız konuşmalarında fikir geliştirecek örneklere yer verilmediği ve konuya tek yönden yaklaşıldığı tespit edilmiştir. Araştırmada elde edilen benzer sonuçlara Çal ve Erdoğan (2017)'a ait araştırmada da rastlanmaktadır. Bu çalışmada da "Türkçe öğretmeni adaylarının konuşmalarında kendilerini ifade etmekte zorlandıkları, telaffuz ve tonlama konusunda her ne kadar hassas olsalar dahi hata yaptıkları" tespit edilmiştir. Ayrıca Türkçe öğretmeni adaylarının dinlediklerinden hareketle yaptıkları hazırlıksız konuşmalarda, serbest bırakılmalarına rağmen, dinlediklerinin aynısını tekrar ifade ettikleri anlaşılmıştır. Yıldırım (2020: 604)'a göre ortaokul öğrencilerinin konuşma sorunlarından bazıları "tekrara düşerek konuşmak, konuşurken gereksiz sesler çıkarmak"tır. Bu sonuç/lar, bu araştırmanın sonuçlarıyla benzerdir. Bu durum, Türkçe öğretmeni adaylarının fikir üretmede, metin üretmede, söylem oluşturmada ve dili etkili kullanmada zayıf olduğunu göstermektedir.

Gündüz (2005) ilköğretim ve ortaöğretimdeki bazı anlatma sorunlarının yükseköğretimde devam ettiğini belirtmektedir. Bu araştırmanın sonucuna göre Türkçe öğretmeni adaylarının dinlediklerinden hareketle yaptıkları hazırlıksız konuşmalarında üstbilişsel becerileri kullanmadığı 
anlaşıımıştır. Türkçe öğretmeni adayları, dinlediklerinden hareketle yaptıkları konuşmalarda söylem oluşturmama, düşünceyi geliştirme yollarına başvurmama ve dili işlevsel kullanmama gibi sorunlar yaşamaktadır. Tuncer ve Bahadır (2017) farklı bölümlerde öğrenim gören öğrencilerin üstbiliş düşünme becerisini kullanma düzeylerinin farklı olduğunu belirtmişlerdir. Dolayısıyla anlama-anlatma becerilerinin gelişiminin Türkçe dersinin amacı olduğu düşünülerek Türkçe öğretmeni adaylarının üstbilişsel metinlerini geliştirmeleri sağlanmalıdır. Konuşma becerisiyle ilgili olarak alıcı sistem, iletici sistem, alt düzeyde tümleyici sistem, üst düzeyde tümleyici sistem, devinimci sistem, duyumlayıcı sistem vb. düzeyler bulunmaktadır. Üst düzey tümleyici sistem aşamasında konuşmaya ilişkin faaliyetleri algılama, anlama, kavrama, iç konuşma, sözel düşünme, konuşmanın planlanması vardır (Uluğ, 1988: 146). Bu araştırmanın sonucuna göre Türkçe öğretmeni adayları, dinlediklerinden hareketle yaptıkları hazırıksız konuşmalarında algılama, kavrama ve konuşmayı planlama aşamalarını pek kullanmamışlardır.

Çelebi ve Gökçe (2015: 200) araştırmalarında Türkçe öğretmeni adaylarının ikna edici konuşmalarındaki tutarlılıkla ilgili sorunlarından birinin "metinde gereksiz tekrarlara ve ilgisiz birimlere rastlanması" olduğunu belirtmişlerdir. Bu araştırmada da benzer sonuca ulaşılımıştır. Konuşma türleri çeşitlik göstermektedir. Bunlardan ön plana çıkan bazıları şunlardır; hazırlıklı konuşma, hazırlıksız konuşma, karşılıklı-tekil konuşma, günlük konuşma, serbest konuşma, tartışma konuşma, bilgilendirici konuşma, betimleyici konuşma vb. (Gündüz, 2009; Güneş, 2014; Temizyürek, Erdem ve Temizkan, 2014). Türkçe öğretmeni adaylarının dinlediklerinden hareketle ne kadar hazırlıksız konuşabildiğiyle ilgili başarı değerlendirilmesinin yapıldığı bu araştırmada, konuşmaların bilgilendirici yöne çekilemediği, tartışmaya girilmediği, sorulan sorulara farklı cevaplar verilmediği sonucuna varılmıştır. Bayburtlu (2019) çalışmasında, ortaokul öğrencilerinin öyküleyici ve açıklayıcı anlatım tarzındaki hazırlıksız konuşma metinlerinde kelime hazinesi oranlarının çoğunlukla orta düzeyde olduğu sonucuna ulaşmıştır. Ancak bu araştırmanın sonucuna göre Türkçe öğretmeni adaylarının dinlediklerinden hareketle yaptıkları hazırlıksız konuşma başarıları "geliştirilebilir" düzeydedir.

Araştırmanın; "Türkçe öğretmeni adaylarının dinledikleri metinlerden hareketle yaptıkları hazırıksız konuşmalardaki söyleyiş, akıcılık, dil yetkinliği ve etkileşim-sunum puanları arasında nasıl bir ilişki vardır?" şeklindeki birinci sorusuna yönelik elde edilen sonuca göre söyleyiş, akıcılık, dil yetkinliği ve etkileşim-sunum puanları arasında anlamlı bir ilişki vardır. Bu, Türkçe öğretmeni adaylarının söyleyiş, akıcılık, dil yetkinliği ile etkileşim-sunum maddelerinden aldıkları puanlar arasında paralelliğin olduğunu göstermektedir.

Araştırmanın; "Türkçe öğretmeni adaylarının dinledikleri metinlerden hareketle yaptıkları hazırlıksız konuşmalarının eğilimi (zayıf-güçlü yönü) nasıldır?” şeklindeki ikinci sorusuna yönelik sonuçları aşağıda verilmiştir.

Konuşma Derecelendirme Ölçeği'nin söyleyişle ilgili maddelerinin toplam puan ortalaması 52,15; gözlem formundan elde edilen söyleyişle ilgili maddelerin toplam ortalaması ise 54,57'dir. Bu istatistikler, Türkçe öğretmeni adaylarının hazırlıksız konuşmalarındaki söyleyişlerinin "geliştirebilir" (40-80) düzeyde olduğunu göstermektedir.

Konuşma Derecelendirme Ölçeği'nin akıcılıkla ilgili maddelerinin toplam puan ortalaması 56,24; gözlem formundaki akıcılıkla ilgili maddelerin ortalama puanı ise 47,74 'tür. Bu istatistikler, Türkçe öğretmeni adaylarının hazırlıksız konuşmalarındaki akıcılığın hem ölçeğe hem de gözlem formuna göre "geliştirebilir" (40-80) düzeyde olduğu sonucuna varılmaktadır.

Konuşma Derecelendirme Ölçeği' nin dil yetkinliğiyle ilgili maddelerinin toplam puan ortalaması 49,16; gözlem maddelerinin içerik-dil kullanımı ile ilgili toplam ortalama puanı ise 42,20 'dir. Bu verilere göre Türkçe öğretmeni adaylarının hazırıısız konuşmalarındaki dil yetkinliği maddelerinin ve içerik dil kullanımı maddelerinin toplam ortalama puanlarının "geliştirebilir" (40-80) düzeyde olduğu tespit edilmiştir.

Konuşma Derecelendirme Ölçeği'nin etkileşim-sunumla ilgili maddelerinin toplam puan ortalaması 47,84; gözlem maddelerinin etkileşimiyle ilgili toplam ortalama puanı ise 53.63 'dür. Bu istatistiksel veriler, Türkçe öğretmeni adaylarının hazırlıksız konuşmaları esnasındaki etkileşimlerinin "geliştirilebilir" (40-80) düzeyde olduğunu göstermektir. 
Araştırmanın; "Türkçe öğretmeni adaylarının dinlediklerinden hareketle yaptıkları hazırlıksız konuşmalarında karşılaşılan sorunlar nelerdir?" olarak ifade edilen üçüncü sorusuna yönelik sonuçları çeşitlilik göstermektedir. Söz konusu Türkçe öğretmeni adaylarının sözlü anlama (dinleme) ve sözlü anlatma (konuşma) becerilerinin zayıf olduğu; dinledikleri tür ile metni ilişkilendiremedikleri; dinlediklerini olduğu gibi özetledikleri; kendilerine özgü üslup oluşturamadıkları; konuşmanın amacını belirleyemedikleri ve konuşmaya etkili başlayamadıkları; konuşmalarının çoğu yerinde gereksiz yinelemelere yer verdikleri tespit edilmiştir. Ayrıca söz konusu adayların konuşmalarında deyim, atasözü vb. unsurlara başvurmadıkları, konuşmalarında düşünceyi geliştirme unsurlarına yer vermedikleri, sorulan soruya uygun cevap veremedikleri, tartışmaya giremedikleri, bürünsel (prozodik) unsurları doğru kullanamadıkları, cümleler arasında mantıksal ve anlamsal bağlantıları yapamadıkları, bağdaşıklık ile tutarlılığı sağlayamadıkları ve söylem oluşturamadıkları sonucuna ulaşımıştır.

Araştırma sonuçlarına göre, Türkçe öğretmeni adaylarının dinlediklerinden hareketle yaptıkları hazırlıksız konuşma başarılarının zayıf yönleriyle ilgili aşağıdaki önerilerde bulunulabilir:

Türkçe öğretmeni adayları, hazırlıksız konuşmalarının etkileyici olması için konuşmanın amacını belirlemeli ve konuşmalarında deyim, atasözü ile diğer düşünceyi geliştirme yollarına başvurmalıdır.

Türkçe öğretmeni adaylarının anlaşılır bir hazırlıksız konuşma yapması için bürünsel (prozodik) unsurları doğru kullanması gerekmektedir. Bunun yanı sıra Türkçe öğretmeni adaylarının etkili bir hazırlıksız konuşma yapmaları için kendilerine özgü söylemlerinin olması gerekir.

Türkçe öğretmeni adaylarının dinlediklerinden hareketle metin-tür ilişkisini kurabilmeleri için üstbilişsel becerileri kullanmaları gerekmektedir. Ayrıca adayların kendilerine özgü söylem oluşturması için eleştirel bakış açısıyla okumalar yaparak dinleme ve konuşmalarını bu bakış açısıyla şekillendirmeleri sağlanmalıdır. Bununla birlikte, Türkçe öğretmeni adaylarının hazırlıksız konuşmalarında cümleler arasındaki mantıksallığa ve anlamlıığa dikkat ederek bağdaşıklık ve tutarlılık bağlantılarını oluşturmaya özen göstermeleri sağlanmalıdır.

Dil becerileri birbirlerini tamamlar, destekler ve geliştirir. Bu bağlamda düşünce planı, yazııı anlatımda planlı yazma, sözlü anlatımda planlı konuşma alışkanlığı daha ilkokul yıllarından itibaren ana dili eğitimi içerisinde etkin olarak verilmeli ve çeşitli dil etkinlikleriyle sözcük dağarcığının zenginleştirilmesi sağlanmalıdır.

Türkçe öğretmeni adaylarının sözlü anlatımlarında veya sözlü iletişimlerinde bağlantı ve metnin (sözlü veya yazılı metnin) devamlılı̆̆ını sağlayan artgönderim ve öngönderim ögelerini uygun biçimde kullanmasına dikkat etmeleri gerekmektedir. Ayrıca söz konusu adayların sözlü iletişim/anlatım durumlarında konuyu sık değiştirmemelerine, uzun süre bir konuyu benzer cümlelerle ifade etmemelerine, anlam bütünlüğünün sağlanmasına özen göstermeleri gerekir.

\section{Kaynaklar}

Akkaya, A. (2012). Öğretmen adaylarının konuşma sorunlarına ilişkin görüşleri. Mustafa Kemal Üniversitesi Sosyal Bilimler Enstitüsü Dergisi, 9(20), 405-420.

Alyılmaz, C. (2010). Türkçe öğretiminin sorunları. Turkish Studies International Periodical for the Languages, Literature and History of Turkish or Turkic, 5(3), 728-749.

Arslan, M. (2017). Ana dili olarak Türkçe öğretimi ve temel dil becerilerinin gelişiminde karşılaşılan sorunlar. Akademik Sosyal Araştırmalar Dergisi, 5(46), 63-77.

Aşılıoğlu, B. (2009). Türkçe öğretmen adaylarına göre derslerde karşılaşılan başlıca dinleme engelleri. Elektronik Sosyal Bilimler Dergisi, 8(29), 45-63.

Aydın, í. (2014). Türkçe öğretiminde yazılı anlatım çalışmalarındaki sorunlar üzerine bir inceleme. Karamanoğlu Mehmetbey Üniversitesi Sosyal ve Ekonomik Araştırmalar Dergisi, 16/Özel Sayı 1, 166-170.

Aytan, T. (2011). Aktif öğrenme tekniklerinin dinleme becerisi üzerine etkileri. Konya: Selçuk Üniversitesi Eğitim Bilimleri Enstitüsü, Doktora Tezi.

Bayburtlu, Y. S. (2019). Öğrencilerin hazırlıksız konuşmalarında kelime hazinesi katsayıları. Ana Dili Eğitimi Dergisi, 8(1), 44-66. 
Birgin, O. (2016). Geçerlik ve değerlendirme standartları. (Çev. Ed.: Mesut Bütün ve Selçuk Beşir) Nitel araştırma yöntemleri/beş yaklaşıma göre nitel araştırma ve araştırma deseni içinde (244-268) Ankara: Siyasal Kitabevi.

Bozkurt, B. Ü. (2017). Türkçe anadili konuşucuları için konuşma becerisi değerlendirme çerçevesi önerisi. Ana Dili Eğitimi Dergisi, 5(4), 924-947.

Bozkurt, B. Ü. ve Arıca-Akkök, E. (2019). Anadili Türkçe olan konuşucular için konuşma becerisi derecelendirme ölçeğinin geliştirilmesi. Elementary Education Online, 18(1), 416-436.

Börekçi, M. (2005). Türkçede vurgu-tonlama-ölçü-anlam ilişkisi. Atatürk Üniversitesi Kazım Karabekir Eğitim Fakültesi Dergisi, 12, 187-207.

Bulut, K. (2015). Mikro öğretim tekniğinin Türkçe öğretmen adaylarının konuşma beceri ve kaygılarına etkisi. Ankara: Gazi Üniversitesi Eğitim Bilimleri Enstitüsü, Doktora Tezi.

Bulut, K., Açık, F. ve Çiftçi, Ö. (2016). Mikro öğretim tekniğinin Türkçe öğretmen adaylarının konuşma becerilerine etkisi. Ana Dili Eğitimi Dergisi, 4(1), 134-150.

Bulut, B. ve Karasakaloğlu, N. (2018). Etkin dinleme eğitiminin dinlediğini ve okuduğunu anlama üzerine etkisi. Kastamonu Education Journal, 26(5), 1407-1417.

Büyüköztürk, Ş., Çakmak, E. K., Akgün, Özcan E. A., Karadeniz, ş. ve Demirel, F. (2015). Bilimsel araştırma yöntemleri. Ankara: Pegem Akademi.

Büyüköztürk, Ş. (2016). Sosyal bilimler için veri analizi el kitabı. Ankara: Pegem Akademi.

Çal, P. ve Erdoğan, E. (2017). Türkçe eğitimi bölümü öğretmen adaylarının konuşma ve yazma becerileri hakkında öğretim üyesi görüşleri. Aydın Tömer Dil Dergisi, 2(2), 1-15.

Ceran, D. (2015). Seçici dinleme ile not alarak dinleme yöntemlerinin altıncı sınıf öğrencilerinin dinlediğini anlama becerisine etkisi. Journal of World of Turks, 7(1), 205-219.

Ceyran, K. O. (2016). Türkçe öğretmeni adaylarının dinleme becerisine yönelik görüşlerinin incelenmesi Nevşehir: Nevşehir Hacı Bektaş Veli Üniversitesi Sosyal Bilimler Enstitüsü, Yüksek Lisans Tezi.

Çelebi, S. ve Gökçe, B. (2015). Türkçe öğretmeni adaylarının ikna edici hazırlıklı konuşmalarında bağdaşıklık ve tutarlıık. International Journal of Language Academy, 3(4), 190-203.

Çifçi, M. (2001). Dinleme eğitimi ve dinlemeyi etkileyen faktörler. Afyon Kocatepe Üniversitesi Sosyal Bilimler Dergisi, 2 (2), 165-177.

Çintaş-Yıldız, D. ve Yavuz, M. (2012). Etkili konuşma ölçeği: Bir ölçek geliştirme çalışması. Turkish Studies International Periodical for the Languages, Literature and History of Turkish or Turkic, 7 (2), 319-334

Delice, A. (2015). Karma yöntem desen seçimi. (Çev. Ed.: Yüksel Dede ve Selçuk Beşir Demir) Karma yöntem araştırmaları/tasarım ve yürütülmesi içinde (61-116) Ankara: Anı Yayıncılık.

Doğan, Y. (2007). Ilköğretim ikinci kademede dil becerisi olarak dinlemeyi geliştirme çalışmaları. Ankara: Gazi Üniversitesi Eğitim Bilimleri Enstitüsü, Doktora Tezi.

Doğan, Y. (2008). İlköğretim yedinci sınıf öğrencilerinin dinleme becerisini geliştirmede etkinlik temelli çalışmaların etkililiği. Türk Eğitim Bilimleri Dergisi, 6 (2), 261-286.

Doğan, Y. (2009). Konuşma becerisinin geliştirilmesine yönelik etkinlik önerileri. Türk Eğitim Bilimleri Dergisi, 7(1), 185-204.

Doğan, Y. (2013). Dinleme eğitimi. Ankara: Pegem Akademi.

Durukan, E. ve Maden, S. (2010). Kavram haritaları ile not tutmanın ilköğretim öğrencilerinin dinlediğini anlama becerisine üzerine etkisi. ODÜ Sosyal Bilimler Enstitüsü Sosyal Bilimler Araştırmaları Dergisi, 1(2), 63-70.

Emiroğlu, S. (2013). Türkçe öğretmeni adaylarının dinleme sorunlarına ilişkin görüşleri. Adıyaman Üniversitesi Sosyal Bilimler Enstitüsü Dergisi, 6 (11), 269-307.

Epçaçan, C. (2013). Temel bir dil becerisi olarak dinleme ve dinleme eğitimi. Adıyaman Üniversitesi Sosyal Bilimler Enstitüsü Dergisi, 6 (11), 231-252.

Erdem, A. ve Erdem, M. (2014). "Dinle izle anlat" dinleme ve konuşma yeterlikleri ölçeğinin geliştirilmesi. Eğitim ve Öğretim Araştırma Dergisi, 4(3),418-432.

Erdem, A. ve Erdem, M. (2015). Yapılandırmacı karma öğrenme ortamlarının dinleme ve konuşma becerilerine etkisi. Elementary Education Online, 14(3), 1130-1148. 
Türkçe Öğretmeni Adaylarının Dinlediklerinden Hareketle Hazırlıksız Konuşma Başarıları: Karma Yöntem Araştırması

Gündüz, O. (2005). Ana dili öğretiminde anlatım sorunları ve çözümüne dair bazı öneriler. Kazım Karabekir Eğitim Fakültesi Dergisi, 12, 20-34.

Gündüz, O. (2009). Konuşma eğitimi. (Ed.: Ahmet Kırkkılıç ve Hayati Akyol), ilköğretimde Türkçe öğretimi içinde (93-133). Ankara: Pegem Akademi.

Gündüz, O. ve Şimşek, T. (2014). Anlama teknikleri 2 dinleme eğitimi. Ankara: Grafiker Yayınları.

Güneş, F. (2012). Öğrencilerin sözlü anlama becerilerini geliştirme. Türkiye Sosyal Araştırmalar Dergisi, $16(2), 10-30$.

Güneş, F. (2014). Türkçe öğretimi yaklaşımlar ve modeller. Ankara: Pegem Akademi.

Güneş, F. (2016). Türkçe öğretiminde beceri uyuşmazlı̆̆ı sorunları ve çözüm önerileri. Bartın Üniversitesi Eğitim Fakültesi Dergisi 5(2), 205-222.

Gürhan, D. (2013). Ses eğitimi çalışmalarının politikacıların konuşma becerilerine etkisi. E-Journal of New World Sciences Academy (NWSA-Fine Arts) 9(1), 33-45.

Hacıömeroğlu, G. (2017). Karma yöntemler. (Çev. Ed.: Beşir Selçuk Demir) Araştırma deseni/nitel nicel ve karma yöntem yaklaşımları içinde (215-239) Ankara: Eğiten Kitap.

Karagündüz, A. (2010). Türkçe ve sınıf öğretmeni adaylarının dinleme stratejilerinin değerlendirilmesi. Erciyes Üniversitesi Sosyal Bilimler Enstitüsü Dergisi. 2 (29). 39-55.

Karatay, H., Dolunay, S. K. ve Savaş, Ö. (2014). Türkçe öğretmenlerinin etkin dinleme ve dönüt durumları. Ana Dili Eğitimi Dergisi, 2(4), 85-106.

Kartallıoğlu, N. (2018). Bilişsel farkındalık stratejilerinin 7. sınıf öğrencilerinin konuşma becerilerini geliştirmeye etkisi. Ana Dili Eğitimi Dergisi, 6(4), 1160-1186.

Kemiksiz, Ö. (2015). Türkçe öğretiminde eleştirel dinleme. Erzincan Üniversitesi Sosyal Bilimler Enstitüsü Dergisi, 9(2), 299-316.

Koç, R. ve Kıymaz, M.S. (2019). Türkçe öğretiminde güncel eğilimler ve sorunlar. (Ed.: Kenan Bulut ve Mehmet Nuri Kardaş) Türkçe Öğrenme ve Öğretme Yaklaşımları içinde (219-235) Ankara: Pegem Akademi.

Korkut, E. (2016). Metin dilbilimi ve dil öğretimi. (Ed.: Ece Korkut ve İrem Onursal Ayırır) Dil eğitimleri ve dil öğretimi içinde (173-202) Ankara: Seçkin Yayıncılık.

Kurudayıoğlu, M. (2003). Konuşma eğitimi ve konuşma becerisini geliştirmeye yönelik etkinlikler. Türklük Bilimi Araştırmaları-13, Türkçenin Öğretimi Özel Sayısı, Bahar, 287- 309.

Kurudayıoğlu, M. ve Savaş, Ö. (2020). Türkçeye uyarlanmış dinleme stili ölçeği'nin değerlendirilmesi. Ana Dili Eğitimi Dergisi, 8(1), 211-216.

Kurudayıoğlu, M. ve Kiraz, B. (2020). Dinleme stratejileri. Ana Dili Eğitimi Dergisi, 8 (2), 386-409 .

Maden, S. (2011). Rol kartlarının konuşma eğitimindeki başarı ve tutum üzerine etkisi. Çankırı Karatekin Üniversitesi Sosyal Bilimler Enstitüsü Dergisi 2(2), 23-38

Maden, S. ve Durukan, E. (2011). Türkçe öğretmeni adaylarının dinleme stillerinin çeşitli değişkenler açısından değerlendirilmesi. Mehmet Akif Ersoy Üniversitesi Sosyal Bilimler Enstitüsü Dergisi, 3(4), 101-112.

Melanlıŏlu, D. (2012a). Dinleme becerisine yönelik ölçme değerlendirme çalışmalarında üstbiliş stratejilerinin kullanımı. International Periodical for the Langueges, Literature and History of Turkish or Turkic. 7(1), 1583-1595.

Melanlıoğlu, D. (2012b). Dinleme becerisinin geliştirilmesinde ailenin rolü. Sosyal Politika Çalışmaları, 7(29), 64-77.

Orhan, S., Kırbaş, A. ve Topal, Y. (2012). Görsellerle desteklenmiş altı şapka düşünme tekniğinin öğrencilerin konuşma becerilerini geliştirmesine etkisi. Turkish Studies International Periodical for the Languages, Literature and History of Turkish or Turkic, 7(3), 1893-1909.

Özbay, M. (2014). Anlama teknikleri ii: dinleme eğitimi. Ankara: Öncü Kitap.

Özbay, M. ve Çetin, Ç. (2011). Dinleme becerisinin geliştirilmesinde prozodik farkındalığın önemi. Muğla Üniversitesi Sosyal Bilimler Enstitüsü Dergisi, (26), 155-176.

Sallabaş, M. E. (2011). Aktif öğrenme yönteminin ilköğretim ikinci kademe öğrencilerinin konuşma becerilerine etkisi. Ankara: Gazi Üniversitesi Eğitim Bilimleri Enstitüsü, Doktora Tezi.

Sargın, M. (2006). Ilköğretim öğrencilerinin konuşma becerilerinin değerlendirilmesi-Muğla ili örneğinde. Muğla: Muğla Üniversitesi Sosyal Bilimler Enstitüsü, Yüksek Lisans Tezi. 
Sevim O. (2012). Öğretmen adaylarına yönelik konuşma kaygısı ölçeği: bir geçerlik ve güvenirlik çalışması. International Periodical for the Languages, Literature and History of Turkish or Turkic, 7/2. 927-937.

Sevim, O. ve Kaya, E . (2016). Ortaokul Türkçe dersi dinleme eğitimi etkinliklerinin öğretmen görüşleri açısından incelenmesi: durum çalışması. Sosyal Bilimler Araştırmaları Dergisi, 11 (1), 277-296.

Şahin, A. (2011). İlköğretim 6. sınıf öğrencilerinin dinleme becerisi farkındalıklarının sosyo-ekonomik düzeye göre incelenmesi. Çankırı Karatekin Üniversitesi Dergisi, 2(1), 178-188.

Şahin, A. ve Aydın, G. (2009). Illköğretim 6. sınıf öğrencilerinin Türkçe dersi dinleme becerisi farkındalıklarının belirlenmesine yönelik bir anket geliştirme. The Journal of International Social Research, 2(9), 454-464.

Temizkan, M. (2009). Akran değerlendirmenin konuşma becerisinin geliştirilmesi üzerindeki etkisi. Mustafa Kemal Üniversitesi Sosyal Bilimler Enstitüsü Dergisi, 6 (12), 90-112.

Temizyürek, F., Erdem, i. ve Temizkan, M. (2014). Konuşma eğitimi. Ankara: Pegem Akademi.

Temizkan, M. ve Atasoy, A. (2016). Konuşma becerisinde aşamalı gelişim modelinin etkililiği üzerine bir değerlendirme. Mustafa Kemal Üniversitesi Sosyal Bilimler Enstitüsü Dergisi, 13 (34), 78-97.

Temur, T. (2010). Dinleme metinlerinden önce ve sonra sorulan soruların üniversite öğrencilerinin dinlediğini anlama becerisi düzeyine etkisi. Selçuk Üniversitesi Ahmet Keleşoğlu Eğitim Fakültesi Dergisi, 29, 303-319.

Tuncer, M. ve Bahadır, F. (2017). Öğretmen adaylarının üstbiliş düşünme becerileri algıları ve başarı yönelimlerine yönelik tutumlarının çeşitli değişkenlere göre değerlendirilmesi. İnsan ve Toplum Bilimleri Araştırmaları Dergisi, 6(2), 1326-1343

Tüzel, S. (2013). Sınıf içi gürültünün öğrencilerin dinleme sürecindeki bilişsel performansına etkisi. Eğitimde Kuram ve Uygulama, 9(4), 363-378.

Tüzel, S. ve Keleş, E. (2013). Dinleme öncesi ve dinleme sonrası verilen soruların 5. sınıf öğrencilerinin dinlediğini anlama beceri düzeyine etkisi. Mustafa Kemal Üniversitesi Sosyal Bilimler Enstitüsü Dergisi, 10(23),27-45.

Uluğ, M. (1988). Konuşma işlevi ve konuşma bozuklukları. Psikoloji Çalışmaları, 16, 141-150.

Yazıcı, E. ve Kurudayıoğlu, M. (2017). 5. sınıf Türkçe ders kitaplarındaki dinleme metinlerinin öğrencilerin seviyesine uygunluğunun incelenmesi. Ana Dili Ĕgitimi Dergisi, 5(4), 967-984.

Yıldırım, A. ve Şimşek, H. (2013). Sosyal bilimlerde nitel araştırma yöntemleri. Ankara: Seçkin Yayıncılık. Yüceer, D. (2014). Türkçe öğretmenliği birinci sınıf öğrencilerinin hazırıksız konuşma becerileri üzerine bir araştırma. Ankara: Gazi Üniversitesi, Yüksek Lisans Tezi.

Yıldırım, N. (2020). Öğretmen görüşlerine göre ortaokul öğrencilerinin konuşma kusurları. Ana Dili Ĕgitimi Dergisi, 8(2), 597-610.

\section{Introduction}

\section{Extended Abstract}

Listening is considered as verbal comprehension, while speaking is considered as verbal expression. Listening, which is the first acquired skill, affects speaking skills indirectly. It is natural for the discourse of an individual who constantly listens to the same music, watches to the same movie or the news in the same channel to be affected by the shows the individual watches or listens to. These two language skills outline the individuals' verbal comprehension skills, emphasizing the significance of conceptual and semantic analysis. The main aim of the present study was to determine the listeningbased impromptu speech achievements of pre-service Turkish language teachers. Thus, the weaknesses and strengths of the pre-service Turkish language teachers in impromptu speech were determined. The study employed the mixed method based on the exploratory design.

\section{Method}

The convenience sampling method was adopted in the study and quantitative data were collected with Speaking Skills Rating Scale and Speaking Skills Observation Form. The qualitative data were collected with the transcripts of the listening-based impromptu speeches by the pre-service Turkish teachers. The study group included pre-service Turkish language teachers attending Adıyaman 
University in Turkey during the 2019-2020 academic year. Convenience sampling method was used in the study. The impromptu speeches were based on the texts on different topics that pre-service Turkish language teachers previously listened. The pre-service Turkish language teachers were allowed to listen various types of texts to determine their achievement levels in impromptu speech based on their comprehension. For the reliability and validity of quantitative data, the Kendall Tau Coefficient was employed for the Speaking Skills Rating Scale and the interobserver agreement coefficient was used for the Speaking Skills Observation Form. To determine the reliability of the qualitative data, the listening-based impromptu speeches were recorded with a voice recorder. The quantitative study data were collected by the mean participant score in the Speaking Skills Observation Form determined by the experts and the mean score assigned by the experts (observers) to the items in the Speaking Skills Observation Form using the SPSS software and presented in tables. The qualitative study data were based on the transcripts of the listening-based impromptu speeches of the pre-service Turkish language teachers

\section{Conclusion and Recommendations}

In the quantitative section of the study, it was concluded that there was a significant and positive correlation between the articulation, fluency, lingual competence and interactionpresentation scores of the pre-service Turkish language teachers in the listening-based impromptu speeches.

The following problems were identified in the impromptu speeches of the pre-service Turkish language teachers in the qualitative section of the study:

$\checkmark$ Poor comprehension (listening) and verbal expression (speaking) skills.

$\checkmark$ Inability to associate the listened type and text.

$\checkmark$ Direct summarization of the listened text, inability to create a unique style.

$\checkmark$ Inability to determine the objective of the speech and to effectively start the speech.

$\checkmark$ Inability to speak naturally and vividly.

$\checkmark$ Inclusion of unnecessary repetitions in the speech.

$\checkmark$ Inability to utilize elements such as idioms, images, proverbs, etc.

$\checkmark$ Lack of idea development elements in the speech.

$\checkmark$ Inability to respond to questions and to discuss during speech.

$\checkmark$ Incorrect use of prosodic elements.

$\checkmark$ Inability to exhibit rational and semantic associations between the sentences.

$\checkmark$ Lack of coherence, consistency, and discourse.

Based on the quantitative and qualitative study findings, it was determined that the impromptu speech achievements of the pre-service Turkish language teachers were mostly at a developable level. Furthermore, it was identified that the fluency, articulation and lingual competence of the pre-service Turkish language teachers in listening-based impromptu speech were poor. Another significant finding was the poor metatextual organizations, discourse, consistency and coherence of the pre-service Turkish language teachers, and their employment of idioms, proverbs and intertextuality in impromptu speech. The following could be recommended about the weaknesses of the pre-service Turkish language teachers in listening-based impromptu speech:

$\checkmark$ The pre-service Turkish language teachers should determine the objective of the speech to make impressive impromptu speeches and utilize methods to use idioms, proverbs and idea development in their speeches.

$\checkmark$ The pre-service Turkish language teachers should correctly employ prosodic elements to make clear impromptu speeches.

$\checkmark$ The pre-service Turkish language teachers should use metacognitive skills to establish a textual-typological correlation based on listening.

$\checkmark$ The pre-service Turkish language teachers should conduct critical reading to develop a unique discourse, and they should listen and speak based on this approach. 
$\checkmark$ The pre-service Turkish language teachers should pay attention to cohesion and consistency based on rationality and semantic associations between the sentences in impromptu speeches.

$\checkmark \quad$ Language skills complement, support and develop one another. Thus, the idea plan, planned written expression, planned speaking habit in verbal expression should be developed in native language education starting from the primary school level, improving vocabulary through various language activities.

$\checkmark$ The pre-service Turkish language teachers should pay attention to the adequate use of anaphoric and cataphoric references that ensure the continuity of the association and the text (verbal or written text) in their verbal expressions or verbal communication. Furthermore, they should pay attention to remaining on the same subject in verbal communication / expression, and to avoid repetition of similar sentences on the same topic, and to ensure cohesion. 